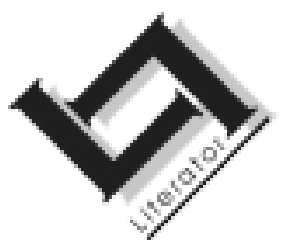

\title{
Antjie Krog se vertaling van Henk van Woerden se roman Een mond vol glas
}

\author{
H.P. van Coller \\ Departement Afrikaans \& Nederlands en Moderne Europese Tale \\ Universiteit van die Vrystaat \\ BLOEMFONTEIN \\ E-pos: fgvc.rd@mail.uovs.ac.za
}

\begin{abstract}
(A)nd can a [wo]man not be a good [wo]man and still be either completely ignorant of all that has pertains to writing, or not have the extensive experience I require of him [her]? I don't call such a person a bad [wo]man, but merely a bad translator (Leonardo Bruni).
\end{abstract}

Abstract

Antjie Krog's translation of Henk van Woerden's novel Een mond vol glas (A mouth full of glass)

Against a historical backdrop several critical approaches to translational theory are explicated. Traditional criticism seems to imply positioning between the Source Text (ST) and the Target Text (TT). A functionalist approach (as propagated among others by Snell-Hornby, Nord and Naaijkens) is a descriptive rather than a normative approach that focuses almost exclusively on the ST. This approach is consequently adopted in the evaluation of Krog's translation; yet even within this more relativistic paradigm, a comparison between ST and TT should not be evaded. In the case of Krog's translation, this comparison leads to the identification of scores of lexical, grammatical and stylistic errors.

\section{Inleidende opmerkings}

Besinning oor die aard van, en noodsaak vir vertaling is net so oud soos die maak van literatuur. In die Babiloniese ryk was vertaling reeds 'n goed gevestigde beroep. Picard (1988:1 e.v.) gee 'n oorsig van antieke vertaalaktiwiteite en in Lefevere (1992) vind 'n mens 'n versameling geordende uitsprake oor vertaling wat oor duisende jare strek. Binne kulture waar kuns gesien is as kommunale aktiwiteit en min waarde 
geheg is aan die persoon van die kunstenaar, het die begrip oorspronklikheid ontbreek. Vertaling in die wydste sin van die woord vertaling as adaptasie, herdigting en herskrywing (Van Gorp et al., 1998:21) was daarom byvoorbeeld in die Middeleeue aan die orde van die dag. Die monumentale oeuvre van Geoffrey Chaucer is hiervan 'n sprekende voorbeeld (Legouis \& Cazamian, 1967:153 e.v.; Benson, 1987). Ook in die Renaissance met sy strewe om die klassieke modelle kwalitatief verby te strewe, was die vertaling van tekste normaal. Begrippe soos imiatio, aemulatio en amplificatio dui almal op prosesse wat naby staan aan wat vandag as vorme van vertaling aanvaar word. 1

Denissen (2000:71) wys daarop dat baie nasionale literature hul ontstaan te danke het aan vertalings. Boonop is uit empiriese gegewens (soos bv. titelbladsye) af te lei dat vertalers in die verlede beskou is as die eweknie van die oorspronklike skrywer: "[D]e vertaler (is) lang niet altijd de knecht (...) geweest waarvoor hij nu wordt versleten." Hierdie negatiewe siening van die hedendaagse posisie van die vertaler word ook geëggo deur Hermans (2000) wat onomwonde stel dat die vertaler deesdae bykans uitgewis word in die vertaalproses. Waar die skrywer eers ambagsman was, word hy na die Romantiek verhef tot kunstenaar en halfgod; navolging wat vroeër positief bejeën is, word nou negatief beskryf as plagiaat. In die negentiende eeu kry ons vir die eerste keer die materiële eiendomsreg op nie-materiële dinge soos idees en later word die fenomeen ook uitgebrei tot produkte van die artistieke gees en sodoende ontstaan outeursreg (Denissen, 2000:72).

Hierdie ontwikkelinge impliseer tans dat outeursreg setel in skrywers (en dat dié reg onlangs ook verleng is tot sewentig jaar na afsterwe). Wie werke waarop daar outeursreg bestaan, wil gebruik (soos veelvuldig aanhaal daaruit, dit uitgee of vertaal) moet betaal. Dit beteken egter ook dat hierdie outeursreg impliseer dat vertalers nie net maar lukraak daarmee kan handel nie, maar die letter en gees daarvan moet respekteer. Daar bestaan talle teoretiese sienings van vertaling as proses van betekenisoordraging (kyk bv. Naudé, 2001, Snell-Hornby, 1995) wat dikwels impliseer dat die vertaler hom op 'n spektrum tussen bronteks $(B T)$ en doelteks (DT) moet plaas.

\section{Vertaalwetenskaplike benaderings: 'n kort oorsig}

Snell-Hornby (1995) en Naudé (2001) bied boeiende oorsigte van teoretiese benaderings tot die vertaalwetenskap. Die eerste suiwer linguis-

$1 \quad$ Vergelyk Pretorius (1972: 66-68 en 134-138) vir 'n uiteensetting van die begrippe aemulatio en imitatio. 
tiese benaderings en modelle ontstaan eers na die Tweede Wêreldoorlog. Die Leipzigskool was linguisties georiënteerd en het getrag om vertaalwetenskap te bedryf op 'n wetenskaplike basis deur op 'n objektiewe wyse te fokus op linguistiese ekwivalensie. Ook Eugene Nida se werk kan gesien word as verwant aan hierdie benadering met as gemeenskaplike faktor die strewe na sogenaamde vertaalekwivalensie het. Die besef het spoedig posgevat dat absolute simmetrie tussen BT en DT onmoontlik is. Nida se teorie van "dinamiese ekwivalensie" wat veel meer pragmaties was, het veral 'n belangrike invloed uitgeoefen op Suid-Afrikaanse vertaalwetenskaplikes. 'n Uitloper hiervan is 'n diskoersanalitiese uitgangspunt (Naudé, 2001:7) wat streef na 'n semantiese en pragmatiese herkonstruksie wat ekwivalensie op 'n tekstuele en kommunikatiewe vlak plaas, en nie op 'n leksikale vlak nie.

Die tweede groot skool van denke rondom vertaling het sy swaartepunt gehad in die algemene literatuurwetenskap en die sisteemteoretiese denke van Itamar Even-Zohar. Waar voorafgaande benaderings altyd die BT sentraal gestel het, rig hulle hul veral op die DT. Hulle sentrale uitgangspunt was dat vertaling altyd 'n manipulering van die BT veronderstel (kyk o.a Toury, 1979:37) en daarom staan hierdie groep vertaalwetenskaplikes ook bekend as die Manipulasie Skool. Hulle het hul benadering duidelik omskryf as deskriptief (en nie normatief) soos vroeëre modelle nie. Voorts het hul veral gekonsentreer op die vertalingsresultaat, eerder as die proses; die vertaalde teks as 'n historiese feit. In hierdie opsig het die insigte van die sisteemteorie 'n belangrike rol gespeel. Literatuur is hiervolgens 'n sisteem van siteme wat voortdurend in stryd verkeer en van hiërargiese posisies verskuif. In die denke van Lefevere en ander is vertaling dus geen neutrale handeling nie, maar 'n magspel. Wat uiters belangrik is, is om te bepaal waarom die doelsisteem byvoorbeeld bepaalde werke uit 'n bronsisteem kies vir vertaling (kyk ook Lefevere, 1992: 1-2, Yahalom, 1979 en Van Gorp, 1979). "Vertaling word nie langer beskou as die herproduksie van 'n oorspronklike teks nie, maar as 'n herkontekstualisering, herskrywing van 'n alreeds gepluraliseerde oorspronklike" (Naudé, 2001:13).

Naudé (2001:9) wys vervolgens ook op prosesgeoriënteerde, resepsiegeoriënteerde en funksionalistiese modelle. Al hierdie benaderings is meer deskriptief van aard en/of DT-georiënteerd. Wat die beoordeling van die vertaling van Henk van Woerden se roman deur Antjie Krog betref, is die teorieë van Nord (1991) van belang omdat sy ook kontekstuele aspekte van die vertaling (soos die opdraggewer) betrek. Uit verskeie uitsprake van Krog is dit duidelik dat sy haar vertaling van Van Woerden se roman sien as primêr gerig op die doelsisteem en dat toeganklikheid vir haar vooropstaan. Maar wat belangrik is, is dat die 
vertaler dan duidelik moet uitspel presies watter aspekte van die BT aangepas word.

Uit sowel Snell-Hornby (1995:39 e.v.) as Naudé (2001:18 e.v.) blyk dat vertaling ' $n$ inter-kulturele handeling is wat tussen kulture bemiddel. Kultuur word deur Snell-Hornby (1995:39) omvattend omskryf as alle sosiaal-gekondisioneerde aspekte van die menslike bestaan. Vanselfsprekend kan daar 'n skaal opgestel word van die kulturele afstand tussen die BT en die DT wat deur vertaling oorbrug moet word. Hofstede (1991) onderskei kulture dus ook van mekaar op grond van veranderlikes soos simbole, helde en rituele. Vertalings kan ook gegradeer word volgens die wyse waarop hulle trag om die oorspronklike werk te akkultureer, wat in wese neerkom op 'n posisie-inname tussen BT en DT.

\section{Vertaalbenaderings, -teorieë en -praktyk in Nederland en Suid-Afrika}

Binne die vertaalpraktyk in Nederland is die algemene opvatting dat 'n vertaling na aan die bronteks moet staan (vgl. De Jong-Goossens, 1998; De Lange, 1998; Dorsman, 1998) iets waaroor Denissen (2000) hom mateloos vererg. Uit die voordragte van lede van die Nederlandse Produktiefonds by die Nederlandse Taalunie se vertalerswerkswinkel van 2000 en uit sowel Daniël Hugo se vertaalbeskouing (1998) as sy eie vertalings, blyk dat dieselfde siening oorheers ten aansien van vertalings uit Nederlands in Afrikaans.

De Stadler (1998) neem daarenteen 'n hele ander standpunt in, maar dan ten aansien van vertaling van (pragmatiese) tekste binne 'n multikulturele omgewing. Hy pleit in so 'n geval vir die primaat van die doelteks wat dikwels nie 'n nougesette vertaling van die bronteks veronderstel nie, maar bykans die skep van 'n nuwe doelteks. Britz (1998) se redenasie dat 'n vertaler hom (veral in die geval van satiriese literatuur) voortdurend moet aanpas by konvensies van die doeltaal én aan die referensiekader van die lesers van die doelteks, gaan in dieselfde rigting. Volgens Britz (1998:20) kan vertalings nooit "bijna exacte replika's van de oorspronkelijke boeken" wees nie en bestaan daar ook nie iets soos 'n implied author wat duidelike wenke gee oor hoe ' $n$ teks in 'n ander taal gelees moet word nie.

Terwyl dit onteenseglik so is dat eenduidige, "ideale" interpretasies binne die huidige literatuurwetenskaplike paradigma ontken word, beteken dit egter nie dat 'n vertaler ten opsigte van "vertolking en evaluatie" (Britz, 
1998:20) 'n vrypas het nie. ${ }^{2}$ Vanselfsprekend sal 'n vertaalde teks se pragmatiese werking binne die nuwe literêre sisteem verskil van dié binne die bronsisteem. Die redes hiervoor het egter veral te make met sistemiese verskille en derhalwe met die wyse waarop die teks tot 'n ander estetiese objek omvorm word; nie noodwendig met die feit dat dit opeens 'n ander materiële objek (artefak) raak nie. Selfs uiters kreatiewe omsettings (soos die Shakespeare-herskrywings van Ton Lanoye), impliseer ' $n$ deeglike kennis van standaard-interpretasies van die bronteks. Vertalers wat implisiete outeurs verfoei, moet hul liefs besig hou met bewerking, "voor de preciezen in de vertalerswereld een vies woord" (Denissen, 2000:75).

\section{Vertaling uit Nederlands in Afrikaans}

Op die vraag waarom vertaling uit Nederlands nodig is, antwoord Daniel Hugo kortweg. Nederlandse boeke is nie beskikbaar in Suid-Afrika nie, nie in Nederlands of in Engelse vertaling nie. Verder is Nederlands as taal ontoeganklik vir baie Afrikaanstalige lesers. Op die eerder gestelde vraag sou meerdere antwoorde gegee kon word. Een van die belangrikste redes vir enige vertaling het te make met die verhouding van die twee tersaaklike litererêre sisteme, dié van die brontaal en dié van die doeltaal. Vertaling staan binne die sisteemteorie bekend as import en dit impliseer dat dit "geïmporteer" of ingevoer word waarvoor daar 'n behoefte bestaan. Die behoefte mag te make hê met bepaalde literêre oorwegings soos temas, stylsoorte, ideologieë óf met bepaalde verbruikersbehoeftes wat direk gevoed mag word deur buite-literêre belangstellings. In die eerste geval word boeke vertaal wat byvoorbeeld aansluit by bepaalde aspekte van die doelsisteem of juis hiate daarin aanvul. In die laasgenoemde geval word werke vertaal uit 'n land wat byvoorbeeld in die belangstelling staan vanweë veelvuldige redes; selfs die vermeende eksotiese aard daarvan.

In die lig van die aantal werke wat gedurende die afgelope jare in Nederlands vertaal is uit Suid-Afrikaanse tale (veral Afrikaans en Engels), staan Suid-Afrika skynbaar in die belangstellingsveld van Nederland. Dat daar egter besluit word om sekere skrywers te vertaal, het nie altyd net met literêre oorwegings te make nie. Breyten

2 Dit is opvallend dat ernstige vertalers (ongeag watter vertaalpraktyk hulle voorstaan) selde 'n boek vertaal sonder dat hulle hul deeglik vergewis het van die stand van die literêre kritiek oor die teks en dat hulle voortdurend trag om die presiese betekenis van leksikale items en verwysings te agterhaal (vgl. De Jong-Goossens, 1998; Dorsman, 1998 en Schiferli, 2001 waar hy dit het oor die Duitse vertaler Gregor Seferens). 
Breytenbach en André P. Brink dank hul bekendheid veral aan hul politieke profiel; Riana Scheepers hare in hoë mate aan haar bemarkbaarheid wat nie los staan van haar voorkoms en algemene openbare optrede nie. 3

Die uitgangspunt ten aansien van die publikasie van Nederlandse literêre tekste in Suid-Afrika was in die verlede heel idealisties. Daar is sonder meer aanvaar dat hierdie kategorie tekste sonder te veel moeite wel toeganklik was vir (Suid-) Afrikaanse lesers. In die reeks "Literatuur uit die Lae Lande", uitgegee deur die uitgewery Human en Rousseau, is "klassieke" Nederlandse tekste daarom in Nederlands gepubliseer met inleidings en verklarende aantekeninge deur Suid-Afrikaanse literatore. Hugo (1998:43) beweer dat Suid-Afrikaanse uitgewers nog nooit gretig was om Nederlandse vertalings te publiseer nie. Uit sy oorsig van vertaalde werke uit Nederlands blyk hierdie feit op onomstootlike wyse. Benewens jeugliteratuur is in die verlede min vertaal; van literêre tekste is daar maar 'n klein handjievol.

Ná 1990 (en veral 1994) was alle Suid-Afrikaners meteens weer aanvaarbaar vir hul Europese stamlande. Vertaling uit Afrikaans in Nederlands neem dramaties toe (kyk Van den Bergh, 2001 en Venter, 2002). 4 Die omgekeerde is egter nie waar nie: na die herstel van kulturele betrekkings verskyn daar min Afrikaanse vertalings van Nederlandse tekste. Vier hiervan is vertalings van Daniel Hugo (Herman de Coninck se Liefde, miskien en Tom Lanoye se Kartondose - albei in 1996 - Harry Mulisch se Die aanslag (1998) en Verhale van Herman van Veen in 2000. In 2000 verskyn ook Antjie Krog se vertaling van Henk van Woerden se roman, Een mond vol glas, onder die titel Domein van Glas en onlangs ook Ahraham de Vries se vertaling van Adriaan van Dis se novelle (en tewens Boekeweek-geskenk), Palmwyn.

Uit die voorafgaande is dit duidelik dat vertaling uit Nederlands in Afrikaans vir Suid-Afrikaanse uitgewerye (ten spyte van finansiële ondersteuning deur die Nederlands Literair Produktie- en Vertalersfonds en die meer resente Vlaams Fonds voor de Letteren) steeds geen prioriteit is nie. Die Nederlandse letterkunde staan skynbaar nie sentraal in die belangstelling van Afrikaanstalige lesers nie; hul verkies veelal die veel makliker toeganklike Engelstalige literatuur wat ook vertalings van

3 In Venter (2002) word dieper ingegaan op aspekte wat 'n rol speel in die keuse van (Suid-) Afrikaanse outeurs vir vertaling in Nederlands.

4 Riet de Jong-Goossens het tussen 1988 en 1996 agttien Afrikaanse boeke vertaal (Hugo, 1998:45). 
die belangrikste internasionale skrywers insluit. Boonop het die vyandige houding van die Belgiese (en veral die Nederlandse) regerings in die laaste paar dekades voor 1994 kulturele uitwisseling tussen Suid-Afrika en sy stamlande onmoontlik gemaak. Die kulturele boikot het van die Nederlandse kultuur nie net iets vreemds gemaak in Suid-Afrika nie; wel iets wat op grond van ideologiese redes dikwels met argwaan bejeën word deur sommige (blanke) Afrikaanssprekendes.

\section{Die evaluering van vertalings}

Tydens die Nederlandse Taalunie se Vertalerswerkswinkel wat van 21 Augustus tot 1 September 2000 gehou is aan die Universiteit van Utrecht en die Katholieke Vlaamse Hogeschool in Antwerpen, is deelnemers blootgestel aan diverse, en dikwels uiteenlopende, invalshoeke wat die praktyk en die teorie van literêre vertalings betref. Dit was veral Ton Naaijkens wat telkens beklemtoon het dat die beoordeling van 'n vertaling eerder moet wegstuur van 'n summiere evaluering en liefs deskriptief behoort te wees. In die praktyk van die vertaalkritiese omgang met die vertaalde teks impliseer dit dat die kritikus trag om te konstrueer wat die vertaler beoog het, hoe die oorspronklike teks begryp is, of die regte middele gebruik is om die nagestrewe doel te bereik en dat die uiteindelike effek beoordeel word.

In 'n beoordeling van die vertaling sal besluit moet word of die vertaling integraal bekyk gaan word of aan die hand van steekproewe beoordeel sal word. Aan die hand van Holmes (1988) se bekende kruismodel kan nagegaan word watter verskuiwings plaasgevind het op verskillende vlakke. Al hierdie verskuiwings kom eintlik neer op posisie-innames van die vertaler tusen bronteks en doelteks. Dit is hieruit duidelik dat die vertaalkritikus hom of haar by implikasie as medevertaler opstel binne 'n bepaalde paradigmatiese opset. In wese verskil dit min van die intersubjektiwiteitstrewe waarvan daar sprake is wanneer ' $n$ interpretasie van byvoorbeeld 'n literêre teks beoordeel word. 'n Kritikus probeer dus aan die hand van 'n gekose teoretiese kader om die ondersoeker op die voet volg sonder om van meet af aan op selfingenome wyse die ondersoekraamwerk te verwerp.

Naaijkens (2000) gee 'n oorsig van verskillende vorme van vertaalkritiek wat wissel van 'n "blinde" beoordeling van die vertaling sonder kennis van die bronteks, foutanalises wat neerkom op blote vergelyking en die uitwys van foute, impressionistiese kritiek wat daarop neerkom dat 'n oordeel berus op eerste indrukke, mededingende kritiek (waar hervertaling ter sprake kom) en die analitiese metode wat Naaijkens as die ideale benadering beskou. Hierdie benadering is pragmaties en relativisties van aard en stel eerder vrae na die doel van die vertaling en die 
wyse waarop die doel nagestreef is. As beskrywende metode stel dit oordele uit en handhaaf dit ' $n$ oop siening van vertaling en die begrip gelykwaardigheid ("ekwivalensie").

Ten spyte van hierdie relativistiese en "oop" benadering van Naaijkens wat sterk geanker is in die uitgangspunte van die poststrukturalisme (waar hiërargie, bron, intensie en outoriteit bevraagteken word) gee hy toe dat vertaalkritiek nooit beoefen kan word sonder dat vergelyking tusen bronteks en doelteks plaasvind nie. So 'n vergelyking versterk uiteraard die outoriteit van die bronteks en mag lei tot 'n foutanalise, maar dit is die enigste wyse waarop historiese, ideologiese en ander verskuiwings werklik vasgestel kan word. Voorts bied vergelyking insig in die uitgangspunte van die vertaler. In my evaluering van Antjie Krog se vertaling sal ek my hou aan Naaijkens ("een vertaalkundige zonder oogkleppen, die niet toevallig ook een uitstekend vertaler is" - Denissen, 2000:76) se uitgangspunte. Dit behels onder meer die versameling van alle relevante gegewens rondom bronteks en doelteks (hoe onbenullig ook al), algemene tipering van die vertaling en vertaler (met aandag aan voor- en nawoorde), tipering van die bronteks, vergelyking van bronteks en doelteks, tipering van die vertaalstyl en vertaaltegniek en afsluitend kritiese konfrontasie met die vertaalopvattings van die vertaler. 5

\section{Die bemarking van die Krog-vertaling}

Uitgewers is traag om vertaalde tekste te publiseer sonder bykomende aspekte wat die bemarkbaarheid daarvan verhoog. In die geval van De Coninck en Lanoye het die verskyning van hul vertalings saamgeval met hul Suid-Afrikaanse rondtoer wat gepaard gegaan het met openbare optredes en voorlesings uit hul werk. Herman van Veen se vertaalde verhale sou bekendgestel word tydens landswye optredes van dié sanger. Die afstel van sy besoek het verkope van die bundel inderdaad ook nadelig beïnvloed. Harry Mulisch het weliswaar nie in persoon meegewerk aan die bemarking van sy vertaalde roman nie, maar die (Engelse) filmweergawe van sy roman is egter wel wyd vertoon in SuidAfrika. Henk van Woerden het Suid-Afrika gedurende die afgelope jare sporadies besoek, maar hy geniet hier geen wye bekendheid nie.

5 Snell-Horby (1995:69 e.v.) illustreer 'n aanpak wat versoenbaar is met Naaijkens se voorstel. Sy stel egter onomwonde (p. 115) dat in die geval van die vertaling van ' $n$ literêre teks die status van die BT hoër is. Naudé se praktiese riglyne om vertalings te beoordeel gaan terug op Lambert en Van Gorp (1985) wat slegs ten dele vergelykbaar is met Naaijkens se aanpak. Dit sluit in die versameling van alle inligting betreffende die DT, die ontleding van die makrostrukturele kenemerke van die DT, bepaling van woordkeuses, styl- en voordragvlakke en ten slotte 'n geheelstudie. Hul benadering is veral gerig op die doelkulktuurstelsel. 
Selfs die opspraakwekkende aard van Van Woerden se teks (die sluipmoord op dr. H.F. Verwoerd) en die feit dat die sluipmoordenaar, Demitrios Tsafendas, toe pas oorlede is, het die uitgawe van hierdie teks in Afrikaans klaarblyklik steeds 'n waagstuk gemaak. Daarom is Antjie Krog waarskynlik as vertaler "gewerf". Krog, 'n bekende en bekroonde Afrikaanse digter, het bekendheid verwerf as politieke aktivis en het in die jare direk voorafgaande aan die Van Woerden-vertaling opgetree as radio-korrespondent van die $\mathrm{SABC}$, gemoeid met die verslaggewing van die landswye verhore van die Waarheids-en Versoeningskommissie. Die verskyning (en latere bekroning) van haar outobiografies-getinte verslag van dié verhore, The Country of my Skull (1998), het haar bekendheid verhoog.

In die reklame vir die Van Woerden-vertaling is die vertaler telkens vooropgeplaas. Vir 'n uitgewery uit die Naspersstal is dit gewoonlik maklik om vooraf vir 'n bepaalde publikasie reklame in sommige van hul koerante en tydskrifte te maak. In Die Volksblad van 21 Februarie 2000 (vgl. Anon. 2000a) verskyn 'n berig oor die vertaling onder die opskrif "Boek oor Tsafendas gaan opslae maak". Ten spyte van die sensasionele opskrif word in die berig geen melding gemaak van die politieke aard van die teks nie. Antjie Krog se naam as vertaler word duidelik genoem, asook die feit dat Van Woerden lank in Suid-Afrika gewoon het. Veral interessant is die strategieë wat aangewend word om die Afrikaanstalige leser van die waarde van die teks te oortuig. Hierdie kanoniserende strategieë sluit in die vermelding dat Van Woerden baie navorsing oor die onderwerp gedoen het, dat die boek benoem was vir een van die belangrikste literêre pryse in Nederland (die Libris-prys), dat dit in Nederland steeds 'n topverkoper is, dat dit ook vertaal gaan word in Noors en Grieks, dat dit by die KKNK in Oudshoorn bekendgestel gaan word by 'n paneelbespreking waaraan "groot geeste" sal deelneem.

In Insig van Maart 2000 (vgl. Anon., 2000c) verskyn daar 'n kort onderhoud met Antjie Krog oor haar vertaling terwyl in kursiewe druk gesê word dat die vertaling in Maart 2000 verskyn en by die Klein Karoo Nasionale Kunstefees bekendgestel sal word. Uit die onderhoud blyk die politieke aard van die teks duideliker, maar dit word steeds in neutrale terme verwoord, sonder byvoorbeeld 'n veroordeling van dr. Verwoerd. Wel word Van Woerden aangeprys omdat hy bekende dinge so nuut kon voorstel. lets van Krog se vertaalopvattinge blyk ook uit dié onderhoud:

Wanneer twee tale so na aan mekaar lê soos Afrikaans en Hollands (sic!), dan raak vertaling 'n verlossende heerlikheid. Wanneer 'n prosaskrywer eintlik 'n digter is, word die vertaler/digter dubbeld beloon. As die tema boonop iets is wat jou interesseer, loop jou beker oor. 
Gesoute vertalers van tekste uit Afrikaans na Nederlands soos Riet de Jong Goossens (1998) en Robert Dorsman (1998) en van Nederlands na Afrikaans (soos Daniel Hugo, 1998) weet dat dit ietwat naïef is om te beweer dat die twee tale Afrikaans en Nederlands "so na aan mekaar lê". Herhaaldelik word gewys op die dwaling van die vermeende ooreenkoms; selfs op leksikale vlak (die sg. "valse vriende") beteken identieke woorde dikwels verskillende dinge. Vanweë die verskillende grammatiese tydsvorme, die sterk invloed van Engels op die Afrikaanse sintaksis, die feit dat die (omgangs)woordeskat van Afrikaans en Nederlands sterk uiteenloop en dat fleksie in Afrikaans anders verloop het as in Nederlands, is die verskille tussen die twee tale eintlik baie groot. As dit nie so was nie, sou vertaling in elk geval nie nodig gewees het nie.

'n Kort stukkie oor die bekendstelling van die vertaling in Kaapstad verskyn in Die Burger van 15 Maart. Weer eens word die vertaler vermeld, maar die politieke aard van die teks blyk reeds duideliker uit die feit dat die boek in die Bo-Kaap Museum bekendgestel word met dr. Fared Esack, lid van die Kommissie vir Geslagsgelykheid as spreker. Van Woerden se teenwoordigheid word ook vermeld, naas die feit dat hy boeke (wat teen 'n spesiale prys beskikbaar gestel sal word) sal teken.

Onder die vreemde opskrif "'n Wêreld van glas" verskyn ook 'n kort mededeling oor die vertaling in Boekewêreld van Maart 2000 (vgl. Anon., 2000c). Weer eens word die klem geplaas op die feit dat Van Woerden die mens Tsafendas teken in sy werk en dat Antjie Krog die boek "uit Hollands (sic!)" vertaal het. Hier word ook vir die eerste keer iets gerep van die keuringsproses van die boek: "In sy keurverslag noem Vernon Februarie dit 'n eina-boek. 'Soms was ek die moer in omdat ek so baie plekke en dinge daarin herken'”. Vir heelwat van die literêr meer ingeligte lesers van Boekewêreld sou die identiteit van Vernon Februarie waarskynlik bekend wees. Februarie is 'n uitgeweke bruin man wat gedigte in Afrikaans geskryf het (bv. opgeneem in die jongste Groot verseboek), is hoogleraar aan die Universiteit van Leiden (en deeltyds aan die Universiteit van Wes-Kaapland) en het ook gepubliseer het oor die Afrikaanse literatuur. Uit die berig is dit egter ietwat onduidelik of Februarie as keurder van die roman of die vertaling daarvan opgetree het. Hoewel die laaste kennelik bedoel word, lyk dit amper asof hy eers van die roman in sy vertaalde vorm kennis geneem het. Wel is duidelik dat Februarie die vertaling goedgekeur het, anders sou hy nie bereid gewees het om sy keuringsverslag vir reklame te laat gebruik nie.

Op 21 Maart verskyn 'n onderhoud met Antjie Krog in Beeld (vgl. Booyens \& Nieuwoudt, 2000:4). Daarin noem sy haar vertaling van Van Woerden se roman "veel veiliger" as 'n eie oorspronklike stuk werk. Die 
grootste uitdaging vir haar as vertaler was die grammatiese tye: "Ek moes deur al die soort verlede tye worstel en dit omskep in wat ons almal elke dag gebruik - die historiese verlede (sic!) tyd".

'n Paar dae later (op 25 Maart 2000) word 'n onderhoud wat Herman Wasserman voer met Henk van Woerden in Die Burger gepubliseer. Hierin word Antjie Krog se naam as vertaler weer eens pertinent genoem, asook die politieke aard van die teks wat deur Van Woerden 'n historiese herkonstruksie, 'n poging tot anamnese, genoem word.

Kwalik twee later verskyn daar weer 'n onderhoud met Van Woerden, maar dié keer met Barry Hough in Rapport van 9 April 2000 (Hough, 2000). Hierin sê Van Woerden dat sy bedoelde leser die bruin Afrikaanssprekende was, "want Tsafendas se dilemma en sy verskeurdheid is tog eintlik dié van die bruin gemeenskap in Suider-Afrika". In sy boek oor 'n "siek maatskappy" wat "ontoerekeningsvatbaar" was, is die geskiedenis van Tsafendas ' $n$ metafoor en in 'n sin die beswering van demone uit sy eie verlede.

In Huisgenoot van 13 April 2000 verskyn 'n stuk onder die opskrif "Sterboek. Uitsoek-leesstof" (vgl. Anon., 2000d) waarin Domein van glas aangekondig word. Terwyl daar gewag gemaak word van die inhoud van die teks ("die verhaal van Dimitri Tsafendas, die man wat dr. Hendrik Verwoerd in 1966 met vier dolkhoue om die lewe gebring het"), word daar vermy om enigsins 'n politieke strekking aan hierdie teks te gee, vermoedelik omdat dit bestem is vir redelik konserwatiewe lesers. Die feit dat Antjie Krog die werk uit Nederlands vertaal het, word pertinent vermeld, asook dat daar verdere vertalings in Grieks, Engels en Noors gaan volg. Tipies van Huisgenoot word daar ook 'n wedstryd uitgeskyf waarin een gelukkige leser die vertaling gratis kan ontvang. Lesers moet tjeks en bestellings instuur en slegs die eerste vyf sal hul geld terugontvang!

In Zuid-Afrika verskyn daar in die Aprilnommer van 2000 (vgl. Anon. 2000e) 'n kort beriggie waarin die vertaling heel neutraal aangekondig word met vermelding van die vertaler se naam.

Theresa Biberauer (2000) skryf op 18 Junie 2000 'n stuk in The Sunday Independent wat naas ' $n$ aankondiging van die Engelse vertaling van Een mond vol glas (deur Dan Jakobson) as A Mouthful of glass, ${ }^{6}$ ook die weergawe van 'n onderhoud met Van Woerden bevat. Dit is opvallend

6 Vir my gevoel (sien Van Coller, 2000:152) is dit - soos later aangetoon sal word - 'n veel beter keuse as dié van Antjie Krog. 
dat hierdie joernalis wat buite die Afrikaanse literêre "circuit" staan7 die naam van die Afrikaanse (en Engelse) vertaler net in die verbygaan noem en geen blyke gee van strategiese posisie-inname binne die literêre veld nie. Haar verslag is redelik neutraal en feitelik.

Ook in die publikasie self verdwyn die vertaler bepaald nie: haar naam verskyn op die voorblad en word prominent vermeld op die titelblad. Talle onderhoude voor (en na) die verskyning van die teks is met haar gevoer waaruit duidelik is dat die vertaling op die rug gery het van haar profiel.

\section{Die vertaling: voorgeskiedenis}

Krog se kennis van Nederlands en die Nederlandse letterkunde is in onbekendheid gehul. Sy het tydens haar studiejare aan die destydse Universiteit van die Oranje-Vrystaat, Afrikaans en Nederlands en Engels as hoofvakke geneem en 'n mens kan aanvaar dat sy wel Nederlandse romans moes bestudeer het. Ten einde subsidie te ontvang van die Nederlands Literair Produktie- en Vertalersfonds moet 'n uitgewer in Suid-Afrika van die dienste gebruik maak van 'n sogenaamde goedgekeurde vertaler. Hierdie status word aan 'n vertaler verleen op grond van 'n proefvertaling van 'n goeie twintigtal bladsye uit 'n Nederlandse teks.

De proefvertalingen worden beoordeeld door adviseurs, ervaren vertalers en deskundigen aan universiteiten en hogescholen. Dat werk wordt anoniem gedaan, de deskundige weet niet wiens werk hij of zij bekijkt, en de vertaler weet niet wie zijn of haar werk heeft bekeken (Van den Ouden, 2000).

Omdat hierdie vertaling wel gesubsidieerd is, kan aanvaar word dat 'n proefvertaling van Antjie Krog wel goedgekeur is deur "deskundiges". Soos later sal blyk, wek dit heelwat vrae.

Ek het as eksterne keurder van die vertaling in Januarie 2000 aanbeveel dat die vertaling grondig hersien moet word vanweë die omvang van foute - dit nadat die vertalingsubsidie reeds goedgekeur is, kennelik op grond van proefvertalings. Omdat die boek bekendgestel moes word tydens die Kleinkaroo se Kunstefees in Maart 2000 was daar nie tyd om ' $n$ addisionele vertaler aan te wys nie. Wel het Antjie Krog ' $n$ maand saam met Henk van Woerden deurgebring waartydens aan die vertaling

$7 \quad$ Vergelyk Dorleijn (1996:51-70) vir 'n bespreking van hierdie begrip wat in hul weergawe van die sogenaamde "literêre veld" (Bourdieu) 'n klein kringetjie rolspelers binne die literêre veld beteken. 
gewerk is. Soos sy in die "Nota van die vertaler" te kenne gee (Krog, 2000:19) het hy haar baie gehelp en dié samewerking "het ook gelei tot allerlei vondse". Dit blyk inderdaad uit die vertaalde werk dat Van Woerden self gewysig het aan sy oorspronklike teks (bv. in sy "Aantekeninge en dankwoord"). By die beoordeling van die vertaling moet hierdie feit verreken word en kan die "onaantasbaarheid" van die bronteks nie vooropstaan nie.

In haar "Nota van die vertaler" stel Antjie Krog haar vertaalopvattings, wat tot dusver sporadies ter sprake gekom het, heel duidelik aan die orde. Sy respekteer die bronteks deurdat sy die "poëtiese wyse waarop Henk van Woerden met taal opgaan" probeer behou. Voorts het sy 'n duidelik histories-gerigte benadering deurdat sy doelbewus trag om "die historiese geheue van Afrikaans te laat seëvier". Dit kom daarop neer dat sy woorde "uit 'n ouer Afrikaanse toonaard" soos "inmiddels", "flink", "vent", "korselig" gaan behou. Weens die grammatiese tydsverskille tussen Afrikaans en Nederlands werk sy deurgaans in die historiese teenwoordige tyd "met slegs enkele aanduidings dat 'n passasie 'n terugblik is".

\section{Kort kensketsing van Van Woerden se "Kaapse siklus"}

Wanneer Henk van Woerden se "Kaapse" trilogie, Moenie kyk nie! (1993), Tikoes (1996) en 'n Mond vol glas (1998) bekyk word, is dit duidelik dat daar 'n sterk eenheidsfaktor aanwesig is. In al drie die tekste word die individuele en kollektiewe hede en verlede in jukstaposisie geplaas, word die outobiografiese elemente benadruk en word die SuidAfrikaanse werklikheid (en landskap) op indeksikale wyse semioties geïnterpreteer. In die eerste werk Moenie kyk nie! is dit Nederland as land van herkoms van die groep immigrante, wat deurgaans gekontrasteer word met Suid-Afrika. In Tikoes keer die hoofpersoon terug na SuidAfrika vir 'n rondrit saam met 'n geliefde, Tikoes. Nie net die geweldgeteisterde land word deurgaans terugskouend vergelyk met die SuidAfrika van die hoofpersoon se jeugjare nie; ook Tikoes se verlede kom stadig uit die verf. Onomwonde word gesuggereer dat 'n mens jou verlede is. Hierdie tese staan sentraal in die slotstuk, 'n Mond vol glas, waar Tsafendas geteken word as 'n persoon wat deur sy verlede gedetermineer word. In al drie romans staan reis voorop: as wegvlug, soeke na, verkenning van. In die laaste werk word Van Woerden se eie kontemporêre reis in Suid-Afrika waar hy kennis maak met sovele verteenwoordigers van die "nuwe" Suid-Afrika deurgaans 'n parallel vir Tsafendas se verbete reise na 'n plek waar hy kan hoort. Voorts figureer ouer reisigers (soos Aletta Jacobs) as skadufigure waarteen die eietydse reis reliëf kry. 
Hoewel die hoofpersone in die eerste twee werke van die trilogie anders heet, is hulle telkens maar net Van Woerden in verhulde vorm. In die laaste werk staan die outobiografiese hoofpersoon voorop en word sy poging om Tsafendas (en Verwoerd) te deurgrond as "halwe" mense, as verteenwoordigers van dié migrant, in wese 'n soeke na die aard van sy eie identiteit en die esssensie van sy eie Self. Eweneens progressief verloop ook die konfrontasie met die land wat agtereenvolgens as anders, dreigend en siek beskrywe word.

In Van Woerden se optiek kan geen persoon onaangeraak bly deur die Suid-Afrikaanse landskap (en werklikheid) nie (...) die oorheersende siening (is) een waar mense ten onder gaan aan die ruimte in die wydste sin van die begrip (Van Coller, 2001:138).

\section{Die resepsie van die vertaling}

Om enigsins vat te kry op (moontlike) verskuiwende oordele (en soms selfs literatuuropvattings) is dit beter om resepsieverslae liefs chronologies te bekyk. Antjie Krog se vertaling het verrassend baie resensies (en besprekings) ontlok as in ag geneem word hoe weinig belangstelling daar eintlik in Suid-Afrika bestaan vir Nederlandse literatuur. Dit is derhalwe duidelik dat die onderwerp (en die vertaler) die belangstelling geprikkel het.

Snyman (2000) bespreek die vertaling in The Cape Times vanuit 'n politieke fokus. Hierdie resensie as evaluering en bekendstelling dien terselfdertyd ook as inleiding van 'n onderhoud met Van Woerden wat op dieselfde bladsy gepubliseer word. Sonder om een keer na die oorspronklike teks te verwys, of te laat blyk dat sy kritiek op vergelyking gebaseer is, noem Snyman Antjie Krog se vertaling "brilliant" en die boek self 'n "evocative masterpiece". Van Woerden word later self aangehaal waar hy ten aansien van die vertaling opmerk "I'm delighted with the Afrikaans". By tye is dit bykans onmoontlik om agter te kom of Snyman sy eie siening weergee of bloot vir Van Woerden opsom waar hy besin oor die aard van historiese toeval en oor die vraag waarom Tsafendas nooit heldestatus verwerf het nie.

Op 27 Maart verskyn 'n resensie in Die Volksblad (Van Coller, 2000:8) wat een van twee negatiewe besprekings van die werk is. In hierdie skerp resensie word veral gefokus op vertaalfoute wat strek van die leksikale vlak tot by register-, styl- en interpretatiewe foute.

Wasserman (2000:15) konsentreer in sy bespreking op die teks (eerder as die vertaling) en plaas dit binne die verband van migranteliteratuur. Uit sy beswaar dat die leser "te min te wete kom oor Van Woerden se 
lewe" blyk dat Wasserman die boek buite sy sikliese verband lees. Wasserman ervaar die historiese teenwoordige tyd "nie oral as natuurlik nie". Sonder illustrasie van wat hy bedoel, is hierdie opmerking redelik sinloos. Volgens hom pla Neerlandismes soos "kletsmajoor" (p. 166) nie, "omdat dit pas by die Nederlandse ek-verteller en aan die verhaal 'n ouwêreldse atmosfeer gee". Dit is 'n uiters vreemde beredenering omdat 'n vertaling werk met die fiksie dat dit in jou eie taal afspeel. Anders sou 'n Sjinese reisiger werklike Sjinese sinsnedes moes gebruik, ensovoorts. Waarom hierdie moderne roman 'n ouwêeldse atmosfeer moet hê, sê Wasserman ongelukkig nie. Hy gee een voorbeeld van 'n foutiewe vertaling ("vervelig" vir die Nederlandse "vervelend") maar besluit "sulke steuringe doen egter min afbreuk".

André P. Brink (2000) bespreek die vertaling vir Sunday Times en noem die vertaling "sensitive", weer eens sonder om voorbeelde te gee waarop hierdie oordeel gebaseer is. In sy uiters positiewe beoordeling van die bronteks sê Brink "what places Van Woerden's book in an entirely different class (as biographies) is the way in which the story of Tsafendas is interwoven with those of other immigrants: notably Verwoerd and the author himself". Ten slotte bevind Brink dat "(a)lthough Krog's translation has some lapses in her grasp of the nuances of Dutch, it does ample justice to the poetic vision of the original". Hieruit moet ons aflei dat Brink die oorspronklike onder oë gehad het.

Die bekende regse politikus vriend en kenner van die werk van $\mathrm{dr}$. Verwoerd, Jaap Marais, reageer skerp op die verskyning van die vertaling (vgl. Marais 2000a en b). Uit sy reaksie is dit duidelik dat hy die hele onderneming sien as bykans 'n verlengstuk van die linkse komplot ten tye van dr. Verwoerd se dood, waaroor hy reeds 'n boek geskryf het (Marais, 1992). Marais se stuk is belangrik omdat dit toon dat Van Woerden in werklikheid bitter min nuwe gegewens rondom Tsafendas en die sluipmoord aan die lig bring, maar dit op 'n ander wyse interpreteer. Van Woerden se beskrywing van Verwoerd as "die kaaskop met die varkneus" maak Marais kennelik woedend en laat Marais opmerk dat Antjie Krog "die vertaalster" se foto op die agterblad van die vertaling afgedruk is. "Dit was met die oog op die neusbeskrywing nie 'n gelukkige ingewing nie, want haar neus op die foto toon nogal 'n ooreenkoms met dié van Verwoerd, met die voordeel beslis aan Verwoerd se kant". 8

8 In die resensie-kopie van Marais wat ek ontvang het (verskaf deur S.A. Media aan die UV-biblioteek) ontbreek die foto (met al die genoemde persone daarop) wat saam met Marais se artikel ter "illustrasie" van sy argument verskyn. Die vraag ontstaan of dit gesensureer is. Na my gevoel is die reaksie van Marais op die teks belangrik as tekenend van die wyse waarop Van Woerden se teks geresipieer is. 
L.S. Venter (2000) se resensie van sowel die Van Woerden-teks as die vertaling daarvan is kwalik positief te noem. Hy verwoord verskeie besware teen aspekte van die roman, soos die doelbewuste soeke na verbande, veral in die slottoneel waar op 'n "maklike allegoriese manier gepraat word van die Sterk Man (dit is die dood) wat wag". Daarom is Venter se slotsom dat "'n Roman wat op so 'n sentimentele en bewus allegoriese noot eindig (...) nie groots of aangrypend genoem (kan) word nie". Van Woerden se verklarende soeke lewer slegs "besonder onhelder" antwoorde op en hy vra of daar in die geval van 'n psigoot ooit van 'n motief gepraat kan word. Venter se oordeel oor die vertaling is verdoemend: daar is "heelwat vertaal- en ander foute" in die vertaling aan te stip en die vertaling word as "oorhaastig" bestempel.

Die resensie van Barry Hough (2000) is veel minder literêr-georiënteerd as dié van Venter en getuig eerder van 'n sterk politieke simpatie met die uitgangspunte van Van Woerden in sy roman. Hy noem dit onomwonde "'n grondige en simpatieke vertolking van Tsafendas se lewe, dade en die faktore wat dit gevorm het", en later "boeiende en toeganklike leesstof". In die slotparagraaf van sy uiters positiewe resensie word die roman 'n reisverhaal genoem "waarin die geestesgoed van 'n sektor van die samelewing wie se stemme eeue lank al onderdruk is, gekarteer word. Van Woerden se insigte oor die "bruin kultuur en Islam, ook sy menings en teorieë oor Pagad, is fassinerend". 9 Hierdie resensie word afgesluit met die mededeling dat Barry Hough 'n bekroonde skrywer en Rapport se kunsredakteur is. Dit is 'n sterk kanoniserende kanttekening.

Die laaste aankondiging (kwalik resensie te noem) verskyn in die Julie/Augustus-nommer van Kaapse Bibliotekaris in die afdeling "Boekresensies". Naas 'n versigtig verwoorde opsomming van die verhaal, word die vertaling (sonder enige verdere toeligting) "briljant" genoem en toeganklik vir die gewone leser. Slegs ingewydes sal weet wie skuilgaan onder die voorletters "EdeR".

Uit die voorafgaande "resepsiegeskiedenis" is dit duidelik dat resensente in verskillende groepe verdeel kan word: persone wat die roman en die vertaling uit 'n ideologiese invalshoek benader en daarteenoor meer

9 Dit is opvallend dat meer negatiewe besprekings van Van Woerden se roman (o.a. Roodt, 2000; Van Coller, 2001 en Venter, 2000) juis dít wat Hough aanprys, op literêre gronde afwys. In die artikel van Van Coller (2001:150-152 word gewys op Van Woerden se besonder oppervlakkige interpretasie van die redes vir die geweld op die Kaapse vlakte en op sy onvermoë om die komplekse Verwoerd-figuur te deurgrond. Roodt (2000:275) praat van "een teleurstellend gebrek aan diepte" en hy betwyfel dit of Van Woerden intellektueel opgewasse was vir die taak wat hy aan homself gestel het. Venter (2000:15) se bedenkinge is reeds te berde gebring. 
literêr-georiënteerde benaderings. Vanselfsprekend is so 'n verdeling nooit absoluut nie: eersgenoemde groep betrek ook literêre argumente in hul diskoerse en laasgenoemde groep se besprekings is seker ook nie ideologies neutraal nie. Eersgenoemde groep val uiteen in diegene wat Van Woerden se boek afkeur omdat dit veral dr. Verwoerd sou beswadder. Jaap Marais is hier eintlik die enigste verteenwoordiger, maar hy skryf twee omvangryke stukke.10 Voorts is daar 'n hele groep resensente wat Van Woerden se werk veral aanprys vanweë die politieke aard daarvan. Albei groepe negeer die kwaliteit van die vertaling totaal of maak (meestal positiewe) uitlatings daaroor wat geen blyke gee dat hul oordele op iets meer as intuïtiewe oordele berus nie. Brink staan op die grens; sy resensie is duidelik ideologies van aard, maar hy beoordeel die teks ook literêr én betrek die vertaling (hoewel skrams) is sy beoordeling. Die laaste groep gee veel meer aandag aan die vertaling self wat om formele redes afgekeur word.

\section{Vertalersintensie en vergelyking van Bronteks en Doelteks}

In pas met Naaijkens (2000) se uitgangspunte is dit billik om eers die vertalersintensie te agterhaal alvorens met 'n uitgebreide vergelyking begin word. In onderhoude, maar veral in die "Nota van die vertaler" verwoord Antjie Krog 'n paar van haar uitgangspunte. Die eerste faset wat voorrang geniet het, was die poëtiese wyse waarop Henk van Woerden met taal omgaan. In haar vertaling het sy soveel as moontlik hiervan behou: "Selfs waar sy taalgebruik miskien nie heel nuut in Nederlands is nie, maar tog in Afrikaans opwindend anders klink, is dit so gelaat'. In 'n onderhoud (Booyens \& Nieuwoudt, 2000) gee sy self 'n voorbeeld van hierdie poëtiese taal wat sy behou het in haar vertaling: "Ons bloemlees deur die voorstede" (p. 28 van Domein van glas).

Die tweede belangrike riglyn is om met tye die geheue van Afrikaans "te laat seëvier. Daar is sekere woorde en uitdrukkings wat nie daagliks in Afrikaans gebruik word nie, maar wat die taal wel onthou - woorde soos inmiddels, flink, vent, korselig - en die gebruik van dié woorde, wat kom uit 'n ouere Afrikaanse toonaard, veroorsaak 'n interessante spanning saam met die tema". Aldus Krog. Ander voorbeelde wat ek kon opspoor, is woorde soos "maas" - p. 71), "steels" (p. 96), "voorkamer" (p. 120), "aangevreet" (p. 121) en "kats" (p. 123). Ek kon nie werklik voorbeelde vind van die "vondste" waarvan Krog praat nie. Ten slotte meld sy dat sy

10 In Biberauer, 2000:13 verwys Van Woerden "wryly" (wrang) na Marais se stukke as "Goebbels-like propaganda penned by Jaap Marais, the H.N.P. leader". 
deurgaans werk in die historiese teenwoordige tyd "met slegs enkele aanduidings dat 'n passasie 'n terugblik is".

\section{Voorbeelde van die vertaling/vertaalprobleme in Domein van glas}

\subsection{Die titel}

Die titel van Van Woerden se roman het aanleiding gegee tot teenstrydige waardebepalings. Vogelaar (1998) bestempel dit as oordrewe en onduidelik. Postel (1999) verklaar die titel deur dit in verband te bring met die verhale van Tsafendas "die transparant gebleven zijn door de jaren en waarheen, aldus de schrijver, alles zichtbaar wordt als een geslepen lens". Met verwysing na Antjie Krog se titel beweer Snyman (2000) dat Van Woerden Tsafendas se verlede sien as verborge onder 'n domein van glas "hidden, yet visible in part, a life in which the reader surprisingly finds his or her own life mirrored".

Uit Van Woerden se roman kan afgelei word dat die oorspronklike titel verband hou met die koloniale verlede wat soos 'n glasskerf in die mond smaak: "(h)et woord 'amok' heeft een koloniale bijsmaak. Het proeft als een glasscherf in de mond" (p. 176). Dit impliseer dat hierdie "herkou" van 'n traumatiese verlede vir én leser (én skrywer) 'n pynlike proses is. Veel van hierdie (primêr politieke) betekenis gaan verlore in die keuse wat Krog maak vir die titel Domein van glas (2000). Dit plaas die fokus eerder op die universeler aard van herskepping van die verlede deur een van die hoofstuktitels tot oorkoepelende titel te verhef. "Domein van glas" slaan veel meer op die universele problematiek van herskepping van die verlede, die verlede wat as 't ware gestol en deursigtig lyk, maar tog enigsins onaanraakbaar bly en andersins daarom juis manipuleerbaar is: "Sy verlede hoort tot die domein van glas, verborge, gesien deur 'n lens met skerp breuke" (p. 167). Vergelyk ook die sitaat op dieselfde bladsy: "Bykans elke detail uit sy bestaan kan na willekeur vergroot of gekleur word, asof hy na homself deur 'n besondere lens kyk". "In die Nederlandse oorspronklike teks staan daar "verbogen" (p. 199) wat natuurlik beteken "verboë" en nie "verborge" nie!

\subsection{Styl}

Daar is verskeie plekke in die vertaling waar Krog in gebreke bly om stilisties vlot te vertaal. Dit strek van in gebreke bly om aspekte van 'n kulturele kode te vertaal (byvoorbeeld die wyse waarop Engels in gesprekke voorkom en byvoorbeeld op kennisgewingsborde verskyn, o.a. soos op p. 33), of om Nederlandse uitdrukkings letterlik oor te sit in 
Afrikaans, die verkeerde taalregister (bv. p. 107 en p. 136) en foutiewe (en selfs anglisistiese) Afrikaans. In die rubriek "Taalfoute en registerprobleme" verskyn talle voorbeelde hiervan. Enkele voorbeelde kan dien as illustrasie.

Vergelyk byvoorbeeld die staccatostyl van Van Woerden (p. 64) se formulering "Kaapstad in het weekend: een feest met een dreigende kant" met Krog se vertaling: "Oor 'n naweek is Kaapstad soos 'n fees met 'n dreigende ondertoon" (p. 56). 'n Ander voorbeeld is die gedeelte op p. 162/163 van die oorspronklike teks (p. $136 / 137$ in die vertaling). Swak woordkeuse en 'n gebrek aan ritme ondermyn hier 'n kerngedeelte van die roman. Boonop word 'n hele sin "Hij is ziek van schaamte en nostalgie" weggelaat.

\subsection{Ideologiese wysigings}

Die boek wemel van wysigings wat as ideologies beskou kan word: "area" in plaas van "krotbuurt" (p. 23), Tsafendas wat hom in die Bybel "verdiep" in plaas van om oppervlakkig daardeur te blaai (p. 74), die hele deurmekaar gebruik van die woord "kleurling" (p. 172), die invoeging ten aansien van David Pratt (p. 186), ensovoorts. Dikwels is dit nie maklik om te bepaal of die wysiging plaasgevind het vanweë ideologiese oorwegings of weens 'n swak begrip van die oorspronklike Nederlands nie.

Ek volstaan met een van die duidelikste voorbeelde:

Soos altyd skeer die meeue oor die Hawekafee. Pagad? Community Forum? Is dit almal gewone ordinêre kriminele, vra ek. Derick lag hartlik. Hulle sê vir my Ali 'Die Skim' Parker wat die groep na die huis van Rashaad gelei het, is 'n vervaardiger van alarminstallasies wat snags sy eie klante beroof. Die helfte van die bendelede is dan self Moslem, waaronder die Staggies. Hulle sê my ook die dwelmgebruik in die gekleurde woonbuurtes is juis ' $n$ teken van toenemende welvaart, 'is 'n middle-class disease'. Is dit 'n volksopstand, gelei deur woedende puriteine? Ek peper Derick met vrae. Hy glimlag. $\mathrm{Na}$ die trauma van Apartheid smag die meerderheid mense in die voorstede en op die Kaapse Vlakte na niks meer as om 'n normale lewe vir hul te skep nie, sê hy (p. 152/153 van die vertaling).

Hier is die ideologiese beeld een van die vraende wit, Nederlandse toeris met meer as oppervlakkige kennis van die Suid-Afrikaanse toestande. Op al die vrae word geen antwoorde verstrek nie; slegs geïmpliseer dat die meeste mense ná Apartheid bloot wil voortgaan met hul lewens.

In Van Woerden se teks (p.181) staan hierdie gedeelte só: 
De meeuwen scheren zoals altijd over het Harbour Café. PAGAD? Community Outreach Forum? Derick moet er hartelijk om lachen. Het zijn allemaal ordinaire criminelen, zegt hij.

Ali 'De Schim' Parker, die posse naar het huis van Rashad leidde, is een fabrikant van alarminstallaties die 's nachts zijn eigen klanten gaat beroven. De helft van de bendeleden zelf moslim, waaronder de Staggies. Het drugsgebruik in de gekleurde wijken is juist een teken van toenemende welvaart, dis 'n 'middle class disease'. Een volksopstand geleid door rabiate puriteinen? Welnee. De meerderheid in de voorsteden en op de Kaapse vlakten wil na het trauma van de apartheid niets liever dan een normale leven opbouwen.

Uit die oorspronklike gedeelte blyk dat baie van die kommentaar op rekening van Derick (en nie die ek-spreker, Van Woerden nie) moet kom. Hierdie inligting (wat in die vertaling as vae bewerings funksioneer) verkry daarmee veel groter waarheidsgehalte. Dit tas die beeld aan van die bruin mense as blote slagoffers en bevat ook skerp kritiek jeens Pagad. Boonop is Derick se laggende reaksie in die eerste gedeelte by implikasie 'n ontkenning van die feit dat die mense kriminele is terwyl hy dit juis beweer in die oorspronklike.

Dit is onduidelik of Krog die verantwoordelikheid hiervoor moet aanvaar, en of sy en Van Woerden saam die besluit geneem het. Wel is dit duidelik dat die wysiging nie meer neerkom op blote vertaling nie, maar op verwerking. Daardeur word én Derick (wat dalk herkenbaar is) beskerm én die ideologiese standpunt teen apartheid en vir die bruin mense as slagoffers versterk.

\subsection{Grammatikale tyd}

Weens die gebrek aan die Imperfektum (die epiese tyd by uitstek) in Afrikaans, is vertalers geneig om deurgaans te vertaal in die praesens (historiese teenwoordige tyd). Hoewel die Perfektum inderdaad 'n tydsvorm is wat tot lomphede aanleiding kan gee, is dit egter dikwels nodig om wel oor te gaan na hierdie grammatiese tydsvorm ten einde verskillende historiese tye, (emosionele) afstand, ensovoorts aan te dui.

In die onderhawige vertaling van Krog negeer sy feitlik deurgaans die belangrike verskil tussen (vertellers)hede en -verlede. Dit spruit waarskynlik uit die feit dat sy die sikliese konteks van hierdie roman buite rekening laat. Veral Moenie kyk nie (1993) dek die jeugjare waarna dikwels terugverwys word in Een mond vol glas. 
Reeds die motto, 'n sitaat van Peter Abrahams (uit 1954), is 'n herinneringsbeeld wat in die oorspronklike Nederlands ook pertinent in die verre verlede geplaas word.

Op p. 15 tot 19 word die oorgang na die verlede knap gehanteer deur dit eers in die verlede te plaas met "het ... ondergaan" en dan in die praesens te vervolg. In die stuk van p. 21 tot 24 daarenteen sou 'n paar merkers in die Perfektum die afstand beter uitgedruk het. Die openingsparagraaf op p. 25 moet egter in die verlede tyd geplaas word om te beklemtoon dat dit 'n durende proses is wat oor jare strek, óf "het ek nie gedroom" óf "bly ek nie droom". Op p. 27 moet die vooruitskouing voorsien word van 'n "sou": "waarmee die Suid-Afrikaanse lewe ingesnoer [sou] word".

Op p. 30 volg'n herinneringsbeeld vanaf die gedeelte "Hier laat ons ons deur 'n branding (sic!) meesleur ..." Die voortdurende heen-en-weerbeweging tussen hede en verlede word deurgaans deur Krog genegeer.

p. 38: "wat later Griekse ere-konsul in Lourenco Marques word" - "sou word ["later Griekshonorair consul in ..."]

Taalfoute en registerprobleme

\begin{tabular}{|c|c|c|c|}
\hline \multicolumn{4}{|c|}{ Taalfoute en registerprobleme (vervolg) } \\
\hline p. & Krog-vertaling & Korrekte vertaling & $\begin{array}{l}\text { Nederlands - } \\
\text { Van Woerden }\end{array}$ \\
\hline 9 & "oorjas" & jas & \\
\hline 9 & "flink neus" & prominente neus & \\
\hline 9 & "opgewerk" & ontsteld & \\
\hline 9 & "skynbaar beter laat voel" & werklik beter laat voel & “werkelijk oplucht” \\
\hline 10 & "aanhoudend” & voortdurend & "steeds" \\
\hline 12 & "staan weer op straat" & is weer op vrye voete & "staat weer op straat" \\
\hline 13 & $\begin{array}{l}\text { "'n matroos wat 'n rukkie } \\
\text { die wal byster geraak het" }\end{array}$ & $\begin{array}{l}\text { 'n matroos tydelik deur } \\
\text { teëspoed getref }\end{array}$ & $\begin{array}{l}\text { "een zeeman voor een } \\
\text { poos aan wal geraak" }\end{array}$ \\
\hline 13 & "vader van die volk" & $\begin{array}{l}\text { vader des volks [beter } \\
\text { keuse binne haar voorkeur } \\
\text { vir argaïese Afrikaans. }\end{array}$ & \\
\hline 13 & "om die hoek in die straat" & op die straathoek & "op de hoek van de straat" \\
\hline 13 & "my afsit" & my dwars in die krop steek & "me tegenstond" \\
\hline 13 & "die Griek wat siek is" & $\begin{array}{l}\text { die ongelukkige Griek wat } \\
\text { siek is }\end{array}$ & “de ongelukkige Griek” \\
\hline 13 & "Sy moeder kom uit die & Sy moeder kom uit die & \\
\hline 14 & "die [...] skrif aan die muur" & $\begin{array}{l}\text { Frlese dorple Grijpskerk } \\
\text { 'n ernstige waarskuwing }\end{array}$ & $\begin{array}{l}\text { "een ijselijk teken aan de } \\
\text { wand" }\end{array}$ \\
\hline 14 & "per geleentheid" & by geleentheid & \\
\hline 17 & "egte stokke" & regte stokke & \\
\hline
\end{tabular}




\begin{tabular}{|c|c|c|c|}
\hline \multicolumn{4}{|c|}{ Taalfoute en registerprobleme (vervolg) } \\
\hline p. & Krog-vertaling & Korrekte vertaling & $\begin{array}{l}\text { Nederlands - } \\
\text { Van Woerden }\end{array}$ \\
\hline 18 & $\begin{array}{l}\text { "op die dalende vlak van } \\
\text { die Suid-Afrikaanse man- } \\
\text { likheid" }\end{array}$ & in die gevaarsone van ... & $\begin{array}{l}\text { "de eerste onschuldige } \\
\text { stap op het hellende vlak } \\
\text { van de Zuid-Afrikaanse } \\
\text { manbaarheid" }\end{array}$ \\
\hline 19 & "onvoltooide mens" & onvolkome mens & "incompleet mens" \\
\hline 21 & "nie kon verduur nie" & nie kon begryp nie & "niet kon vatten" \\
\hline 21 & "was etlike moorde ..." & was al etlike moorde ... & "al ettelijke moorden ..." \\
\hline 21 & $\begin{array}{l}\text { "so dat haar vingertoppe } \\
\text { daarvan jubel" }\end{array}$ & $\begin{array}{l}\text { sodat ook haar vingerpunte } \\
\text { omhoog gestaan het }\end{array}$ & $\begin{array}{l}\text { "zodat ook haar vinger- } \\
\text { toppen op jubel stonden" }\end{array}$ \\
\hline 21 & "buurthuis" & byeenkomsplek & \\
\hline 22 & & & \\
\hline 25 & "vensterraam" & $r$ & "raam" \\
\hline 25 & "rakeling & soeklig & $\begin{array}{l}\text { "strijklicht" ("Strijkelings" } \\
\text { beteken wel "rakelings") }\end{array}$ \\
\hline 26 & "of dit gewoond is" & of ooit daar gewoon het & $\begin{array}{l}\text { "of ooit (onder de berg) } \\
\text { gewoond heeft" }\end{array}$ \\
\hline 27 & "met haar kuier" & el & "kunnen kuieren" \\
\hline 27 & ol" & & "zit $r$ \\
\hline 28 & $\begin{array}{l}\text { "op die spoor van Aletta } \\
\text { Jacobs" }\end{array}$ & $\begin{array}{l}\text { op die spoorlyn wat Aletta } \\
\text { Jacobs so aangeprys het }\end{array}$ & $\begin{array}{l}\text { "met het spoor dat Aletta } \\
\text { Jacobs roemde", op p. } 29 \\
\text { van Een mond vol glas }\end{array}$ \\
\hline 28 & "'n Engelse vrou" & 'n ouerige Engelse vrou & $\begin{array}{l}\text { "oudere Engelssprekende } \\
\text { vrouw }\end{array}$ \\
\hline 28 & "Asof di & & "ve \\
\hline 28 & skien wel & miski & "misschien wel" \\
\hline 28 & $\begin{array}{l}\text { "Alkohol vernietig jou brein- } \\
\text { selle" }\end{array}$ & & $\begin{array}{l}\text { "Alcohol Destroys Your } \\
\text { Brain Cells!" Vir outentifise- } \\
\text { ring is dit beter om in die } \\
\text { oorspronklike Engels te bly. }\end{array}$ \\
\hline 29 & "strawwe see" & 0 & "stra \\
\hline 29 & & kaart & $\begin{array}{l}\text { "ondoorgrondelijk straten- } \\
\text { plan" }\end{array}$ \\
\hline 29 & $\begin{array}{l}\text { "'n gestriemde onderne- } \\
\text { ming" }\end{array}$ & onaangename ervaring & $\begin{array}{l}\text { "elke vakantie tot een } \\
\text { gestriemde onderneming" }\end{array}$ \\
\hline 29 & "afwykende volkere" & on & "afwijkend volk" \\
\hline 30 & & sma & "een \\
\hline 31 & $\begin{array}{l}\text { "Hande wat nie beweeg } \\
\text { nie" }\end{array}$ & wat nie bev & "die niet beven" \\
\hline 32 & $\begin{array}{l}\text { "Sy was nie altyd so vroom } \\
\text { nie" }\end{array}$ & $\begin{array}{l}\text { waarskynlik nie altyd so } \\
\text { vroom nie }\end{array}$ & $\begin{array}{l}\text { "Zij zal niet altijd zo vroom } \\
\text { zijn geweest" }\end{array}$ \\
\hline 33 & "Ons vertrek uit ..." & ry vinnig weg & "snellen weg" \\
\hline 33 & & & "eer \\
\hline 33 & "Wit Mag" & White Power & $\begin{array}{l}\text { "White Power" Duidelik as } \\
\text { toespeling op Black Power }\end{array}$ \\
\hline 33 & "gier" & lag & "gieren" \\
\hline 33 & "Meeue haak in die wind" & sit vas in & $\begin{array}{l}\text { "Meewen haken in een } \\
\text { wind" }\end{array}$ \\
\hline 33 & $\begin{array}{l}\text { "Daar is opvallend baie } \\
\text { oues van dae" }\end{array}$ & Daar stap opvallend & $\begin{array}{l}\text { "wandelen opvallend veel } \\
\text { ouderen" }\end{array}$ \\
\hline 33 & $\begin{array}{l}\text { "Van die jongeres is gebo- } \\
\text { re" }\end{array}$ & $\begin{array}{l}\text { Van die jongeres is die } \\
\text { meeste eers gebore ... }\end{array}$ & $\begin{array}{l}\text { "zijn de meesten past na } \\
\text { mijn vertrek geboren" }\end{array}$ \\
\hline
\end{tabular}




\begin{tabular}{|c|c|c|c|}
\hline \multicolumn{4}{|c|}{ Taalfoute en registerprobleme (vervolg) } \\
\hline p. & Krog-vertaling & Korrekte vertaling & $\begin{array}{l}\text { Nederlands - } \\
\text { Van Woerden }\end{array}$ \\
\hline 34 & sand" & ut(agtigheid) & "zilt" \\
\hline 34 & andag" & & $\begin{array}{l}\text { "hoe gaat er op scholen } \\
\text { aan toe?" }\end{array}$ \\
\hline 34 & "trein eindelik inkom" & eindelik (aan)kom & "binnentrekt" \\
\hline 35 & & & "gestommel" \\
\hline 35 & sle & & "sleurt" \\
\hline 35 & "uittrek" & ek & "optrekken" \\
\hline 35 & $\begin{array}{l}\text { "Saans besoek ek 'n steak- } \\
\text { house" }\end{array}$ & ie aand besoek ek ... & \\
\hline 35 & "ongehoorsame perd" & hals & "stout perd" \\
\hline 35 & "fort & & "fort van vlees" \\
\hline 35 & "sy snel op my & nnig na my toe & "aan komt snelwandelen" \\
\hline 35 & "tot die laaste & $\begin{array}{l}\text { tot die laaste asemtog/met } \\
\text { my laaste kraginspanning }\end{array}$ & "tot de laatste snik" \\
\hline 36 & $\begin{array}{l}\text { "Suid-Afrikaners (is) ver- } \\
\text { slaaf aan swaarbelaaide } \\
\text { tafels" }\end{array}$ & verslaaf aan baie eet & "het zware tafelen" \\
\hline 36 & $\begin{array}{l}\text { "Wie ná sonsondergang } \\
\text { weer honger was, kon in } \\
\text { die kombuis of spens ge- } \\
\text { braaide varkvelkrakelings } \\
\text {... opspoor" }\end{array}$ & $\begin{array}{l}\text { Wie na sonsondergang nog } \\
\text { honger was, sou in die kom- } \\
\text { buis of spens aangetref kon } \\
\text { word, vuiste vol met kaiings } \\
\text {... }\end{array}$ & $\begin{array}{l}\text { "Wie na zonsondergang } \\
\text { weer hongerde was in de } \\
\text { kombuis of spens te vin- } \\
\text { den, knuisten vol knappe- } \\
\text { rige swoerd ..." }\end{array}$ \\
\hline 36 & $\begin{array}{l}\text { "van die blakende, vet, vro- } \\
\text { like Afrikanerboere" }\end{array}$ & $\begin{array}{l}\text { van die stralende, Afrikaner- } \\
\text { boere met hul hoede }\end{array}$ & $\begin{array}{l}\text { "op de erven van de bla- } \\
\text { kende, goedgemutste }\end{array}$ \\
\hline 39 & "Die streek lê veral nog & lê voorlopig nog & $\begin{array}{l}\text { Afrikanerboere" } \\
\text { "ligt vooralsnog" }\end{array}$ \\
\hline 39 & "katc & & "ka \\
\hline 39 & $\begin{array}{l}\text { "In die somer slaap hy op } \\
\text { die terras" }\end{array}$ & vanweë die hitte op & "vanwege \\
\hline $\begin{array}{l}40 \\
40\end{array}$ & "verskillende spoorlyne" & verskillende maatskappye & "verschillende diensten" \\
\hline 40 & $\begin{array}{l}\text { "Mimis sou na die besoeke } \\
\text { uitgesien het }\end{array}$ & $\begin{array}{l}\text { bietjie afgetrokke is } \\
\text { Mimis het seker/waarskynlik } \\
\text { uitgesien na hierdie besoeke }\end{array}$ & $\begin{array}{l}\text { "wat teruggetrokken" } \\
\text { "zal naar de bezoeken } \\
\text { hebben uitgekeken" }\end{array}$ \\
\hline 40 & & et & "zal het \\
\hline 41 & "is dit moeilik" & is dit a & "eerst moeijlijk" \\
\hline 43 & $\begin{array}{l}\text { "Sy praat oor die ingenieur } \\
\text { van die Suezkanaal, De } \\
\text { Lesseps ... Na ete sleep sy } \\
\text { dik boeke oor die tafel, en } \\
\text { begin die kinders leer" }\end{array}$ & $\begin{array}{l}\text { Sy vertel oor De Lesseps en } \\
\text { die bou van die Suezkanaal } \\
\ldots \text {.. Na ete bring sy dik boeke } \\
\text { tafel toe en begin die kinders } \\
\text { leer }\end{array}$ & $\begin{array}{l}\text { "gaat over De Lesseps en } \\
\text { de bouw van het Suez- } \\
\text { kanaal ... Na het eten } \\
\text { slepen zij dikke boeken ..." }\end{array}$ \\
\hline 4 & $\begin{array}{l}\text { "Binne 'n halwe jaar het die } \\
\text { rusies }\end{array}$ & $\begin{array}{l}\text { Na ongeveer een en 'n half } \\
\text { jaar }\end{array}$ & "Na ruim anderhalf jaar" \\
\hline 4 & "speelfilm" & & "speelfilm" \\
\hline 49 & $\begin{array}{l}\text { "Die dae van } 1934 \text { en } 1935 \\
\text { sal in sy belewing wel die } \\
\text { pynlikste geteken word, } \\
\text { dae waarin hy die vatbaar- } \\
\text { ste was vir verderf" }\end{array}$ & $\begin{array}{l}\text { Die dae van } 1934 \text { en } 1935 \\
\text { sal in sy belewewing waar- } \\
\text { skynlik die pynlikste misvorm } \\
\text { word, die meeste vatbaar } \\
\text { wees vir 'n nog slegter voor- } \\
\text { stelling }\end{array}$ & $\begin{array}{l}\text { "De dagen ... zullen in zijn } \\
\text { beleving wellicht het pijn- } \\
\text { lijkst worden verteken, het } \\
\text { meest vatbaar zijn voor } \\
\text { bederf" }\end{array}$ \\
\hline
\end{tabular}




\begin{tabular}{|c|c|c|c|}
\hline \multicolumn{4}{|c|}{ Taalfoute en registerprobleme (vervolg) } \\
\hline p. & Krog-vertaling & Korrekte vertaling & $\begin{array}{l}\text { Nederlands - } \\
\text { Van Woerden }\end{array}$ \\
\hline 50 & "'n 'naturel"” & 'n autochtoon & "naturel" \\
\hline 51 & "wys hom die deur" & n weg & $\begin{array}{l}\text { "wijst hem het gat van de } \\
\text { deur" }\end{array}$ \\
\hline 51 & $\begin{array}{l}\text { "mag gratis 'n eksemplaar } \\
\text {... saamneem" }\end{array}$ & $\begin{array}{l}\text { mag altyd 'n gratis eksem- } \\
\text { plaar }\end{array}$ & "steeds gratis" \\
\hline 51 & "stewig en flink soos sy pa" & "net so groot soos sy pa & $\begin{array}{l}\text { "al even uit de kluiten ge- } \\
\text { wassen als ziin vader" }\end{array}$ \\
\hline 53 & "afsuig" & suig & "afzuigen" \\
\hline 53 & "'ek wil gewoon naai"” & vil naai'” & ten"” \\
\hline 54 & "middestad n & al neem & "zal \\
\hline 54 & "beskadigde Mercedes" & edes vol duike & "gebutste Mercedes" \\
\hline 54 & "nasaal opklink" & na & "nasaal uitslaat" \\
\hline 54 & "Ka & 'n & "eer \\
\hline 55 & aatplan" & die & "het stra" \\
\hline 56 & "flukse sluk" & gro & "een \\
\hline 56 & $\begin{array}{l}\text { "minste weerstand. Skouer- } \\
\text { bandjies sny ..." }\end{array}$ & $\begin{array}{l}\text { weerstand. Hemde plak aan } \\
\text { lywe. Skouerbandjies sny ... }\end{array}$ & $\begin{array}{l}\text { "weerstand. Hemden plak- } \\
\text { ken ..." }\end{array}$ \\
\hline 58 & "uitle & ver & \\
\hline 58 & $\begin{array}{l}\text { "stotend ... in 'n staat van } \\
\ldots \text {.." }\end{array}$ & hortend ... in 'n toestand van & \\
\hline 58 & "die stad se vermoeidheid" & die stedelike vemoeidheid & "de stadse vermoeidheid" \\
\hline 58 & "die & & "ove \\
\hline 59 & $\begin{array}{l}\text { "geluide klink beide na 'n } \\
\text { skor gejammer ..." }\end{array}$ & $\begin{array}{l}\text { vergesel van 'n skor gewee- } \\
\text { klaag ... }\end{array}$ & $\begin{array}{l}\text { "begeleidend schor ge- } \\
\text { jammer" }\end{array}$ \\
\hline 59 & "jas" & $\mathrm{ba}$ & "jasje" \\
\hline 60 & $\begin{array}{l}\text { "Vind die chaffeur ook die } \\
\text { snelweg vreesaanjaend?" }\end{array}$ & $\begin{array}{l}\text { Die bestuurder vind ook die } \\
\text { snelweg onaangenaam }\end{array}$ & $\begin{array}{l}\text { "De chaffeur vindt de snel- } \\
\text { weg eng" }\end{array}$ \\
\hline 61 & "agte & kop & "ach \\
\hline 61 & $\begin{array}{l}\text { "soos elkeen hom die detail } \\
\text { van sy skoolbank kan her- } \\
\text { inner }\end{array}$ & $\begin{array}{l}\text { Soos elkeen } \\
\text { hede die pos } \\
\text { skoolbank ka }\end{array}$ & $\begin{array}{l}\text { "in detail de positie van zijn } \\
\text { schoolbankje herinnert" }\end{array}$ \\
\hline 61 & $\begin{array}{l}\text { "Ek loop vinnig om die } \\
\text { hoek" }\end{array}$ & $\begin{array}{l}\text { Wanneer ek klaar is, loop ek } \\
\ldots\end{array}$ & $\begin{array}{l}\text { "Na afloop ging ik snel de } \\
\text { hoek om" }\end{array}$ \\
\hline 63 & "aan die kaak" & aar & kaak" \\
\hline 63 & "Ek strooi my kleingeld" & Ek & "lk strooi met kleingeld" \\
\hline 63 & "agent & iebeampte & "age \\
\hline 64 & "Prosesse" & & "processen" \\
\hline 64 & "dagb & $\mathrm{kc}$ & "das \\
\hline 64 & "al om die ander uur" & & "om de zoveel uur" \\
\hline 64 & "tas vol" & "han & "de tas" \\
\hline 65 & "vat" & & "raap" \\
\hline 65 & prosesse" & & "immoraliteisprocessen" \\
\hline 65 & "kokhalsend" & $\begin{array}{l}\text { gewalg/op die punt om te } \\
\text { braak }\end{array}$ & "kokhalzend" \\
\hline 65 & $\begin{array}{l}\text { "weet ek nie waarheen om } \\
\text { met my woede te gaan nie" }\end{array}$ & $\begin{array}{l}\text { weet ek nie hoe om my } \\
\text { woede te beheer nie }\end{array}$ & $\begin{array}{l}\text { "wat ik met mijn woede } \\
\text { aanmoet" }\end{array}$ \\
\hline 65 & "voorstelling & inde & "ops \\
\hline 66 & "hulle lyk teruggeroep" & $\begin{array}{l}\text { ook hulle is weer terugge- } \\
\text { vind }\end{array}$ & $\begin{array}{l}\text { "Ook die zijn zo weer te- } \\
\text { ruggevonden" }\end{array}$ \\
\hline 67 & "inge & veroorsaak deur & "ingesleten door" \\
\hline 68 & "As ons ... bereik" & wanneer ons ... bereik & "als ..." \\
\hline
\end{tabular}




\begin{tabular}{|c|c|c|c|}
\hline \multicolumn{4}{|c|}{ Taalfoute en registerprobleme (vervolg) } \\
\hline p. & Krog-vertaling & Korrekte vertaling & $\begin{array}{l}\text { Nederlands - } \\
\text { Van Woerden }\end{array}$ \\
\hline 72 & "geselserige" & praatlustige & "praatgrage" \\
\hline 73 & "op die tafel te kry" & opgelos te kry & "aan te ka \\
\hline 73 & "jaag hom die strate in" & jaag hom weg & "de laan uitgestuurd" \\
\hline 73 & "om die uur of vyf wakker" & al teen vyfuur wakker & "om een uur of vijf gewekt" \\
\hline 74 & $\begin{array}{l}\text { "soms verdiep hy hom in } \\
\text { die Engelse Bybel" }\end{array}$ & lees hy oppervlakkig in ... & "grasduint hij" \\
\hline 74 & "ruweling" & lummel & "rouwdouwer" \\
\hline 75 & hou" & hou & "staande weet te houden" \\
\hline 75 & kryf"” & refung & "keurig" \\
\hline 76 & "die mees & nuutste/jongste & "de meest recente" \\
\hline 76 & "duik ... in die lêers" & krap & $\begin{array}{l}\text { "duikt een amptenaar ... in } \\
\text { de dossiers" }\end{array}$ \\
\hline 77 & "halfbloed" & baster & "halfl \\
\hline 77 & pe te kom" & $\begin{array}{l}\text { daarvandaan per boot te } \\
\text { vertrek }\end{array}$ & "in $t$ \\
\hline 79 & "snal & la land & "snakt" \\
\hline 79 & lighede" & andighede & omstandic \\
\hline 81 & $\begin{array}{l}\text { "Geen eenvoudige opgawe } \\
\text { van 'n man wat vermoede- } \\
\text { lik net soveel persoonlik- } \\
\text { hede as name het nie" }\end{array}$ & $\begin{array}{l}\text { Nie 'n maklike opdrag waar } \\
\text { dit gaan om 'n man wat } \\
\text { netsoveel persoonlikhede } \\
\text { as name het nie }\end{array}$ & $\begin{array}{l}\text { "Geen gemakkelijke opga- } \\
\text { ve waar het een man be- } \\
\text { treft die er evenveel per- } \\
\text { soonlijkheden als namen } \\
\text { op nahoudt" }\end{array}$ \\
\hline 81 & "sold & S & "lasser" \\
\hline 81 & $\begin{array}{l}\text { "Piraeus, in die laat lig van } \\
\text { die Oktoberdag in 1947: 'n } \\
\text { omgetuimelde boks blok- } \\
\text { kies gehawend deur oor- } \\
\text { logsaktiwiteite" }\end{array}$ & $\begin{array}{l}\text { "geboue" ontbreek wat die } \\
\text { betekenis vertroebel }\end{array}$ & $\begin{array}{l}\text { "een omgekieperde blok- } \\
\text { kendoos van door oorlogs- } \\
\text { handelingen gehavende } \\
\text { gebouwen" }\end{array}$ \\
\hline 81 & $\begin{array}{l}\text { "wat nou op 'n bloedige } \\
\text { burgeroorlog uitgedraai het" }\end{array}$ & uitgeloop het & "is uitgedraaid" \\
\hline 82 & "in gemeen" & ger & "zoveel gemeen" \\
\hline 83 & "in & $\mathrm{b}$ & "bez \\
\hline 84 & $\begin{array}{l}\text { "iemand wat altyd oor ver- } \\
\text { meende onreg kla" }\end{array}$ & $\begin{array}{l}\text { moeilikheidmaker/ kwaad- } \\
\text { stoker }\end{array}$ & "querulent" \\
\hline 85 & "wuif ... uit sy kantoor uit" & stu & "wui \\
\hline 86 & & & "kra \\
\hline 89 & der" & & "las \\
\hline 92 & & & "on \\
\hline 92 & $\begin{array}{l}\text { "Die glans van gestaalde } \\
\text { kaders (?) en die aantrek- } \\
\text { kingskrag van rewolusionêr } \\
\text { klinkende slagspreuke is } \\
\text { lankal hier verby" }\end{array}$ & $\begin{array}{l}\text { die aantrekkingskrag van } \\
\text { onbuigsame groepe en die } \\
\text { aantrekkingskrag van rewo- } \\
\text { lusionêr klinkende slag- } \\
\text { spreuke is al lankal hier } \\
\text { verby }\end{array}$ & $\begin{array}{l}\text { "De glans van gestaalde } \\
\text { kaders en de aantrekkings- } \\
\text { kracht van revolutionair } \\
\text { klinkende slogans heeft } \\
\text { hier zijn langste tijd gehad" }\end{array}$ \\
\hline 96 & roene'”' & sak in my skoene & "zinkt me in de schoenen" \\
\hline 97 & & & "sto \\
\hline 97 & "vervelic & onaangenaam optree & "vervelend" \\
\hline 99 & "weggepink" & we & "weggepinkt" \\
\hline 100 & "'n skoonheid" & $\begin{array}{l}\text { 'n pragtige/ beeldskone } \\
\text { meisie }\end{array}$ & "een schoonheid" \\
\hline 100 & "wiebelrig" & wankelend & "wiebelend" \\
\hline
\end{tabular}




\begin{tabular}{|c|c|c|c|}
\hline \multicolumn{4}{|c|}{ Taalfoute en registerprobleme (vervolg) } \\
\hline p. & Krog-vertaling & Korrekte vertaling & $\begin{array}{l}\text { Nederlands - } \\
\text { Van Woerden }\end{array}$ \\
\hline 100 & "suinig toe" & 'n bietjie toe & "zuinigjes" \\
\hline 101 & $\begin{array}{l}\text { "nog 'n keer die strafroete } \\
\text { te loop nie" }\end{array}$ & $\begin{array}{l}\text { nog 'n keer afgeransel te } \\
\text { word }\end{array}$ & "spitsroede te lopen" \\
\hline 103 & "afsuig” & ale seks/suig & "pijpen" \\
\hline 105 & $\begin{array}{l}\text { "in 'n apepak, met 'n pith } \\
\text { helmet" }\end{array}$ & $\begin{array}{l}\text { in 'n opvallende uniform, } \\
\text { met 'n helm bestem vir die } \\
\text { trope }\end{array}$ & $\begin{array}{l}\text { "in een apenpakje, met } \\
\text { tropenhelm" }\end{array}$ \\
\hline 106 & "veiligheidskeuring" & ligheidskontrole & "veiligheidskeuring" \\
\hline 106 & $\begin{array}{l}\text { "stotter mense oor die } \\
\text { Hottentotshollandpas" }\end{array}$ & or ... & "stottert" \\
\hline 107 & $\begin{array}{l}\text { "ek help jou effektief die } \\
\text { ewigheid in" }\end{array}$ & ek maak jou van kant & $\begin{array}{l}\text { "ik help je efficiënt om } \\
\text { zeep" }\end{array}$ \\
\hline 108 & "re & kvisum & isvisum" \\
\hline 110 & vergeet nie" & & yeten" \\
\hline 110 & "Inspekteur Ferreira" & $\begin{array}{l}\text { (in die jare sestig?) Eerder: } \\
\text { kaptein of gelyke rang. }\end{array}$ & "inspe \\
\hline 111 & "Hy pak die Bybel ... in" & $\begin{array}{l}\text { vat ook die Bybel op sy } \\
\text { bedkassie }\end{array}$ & "neemt ook ..." \\
\hline 112 & "'n mond vol Duits" & Duits & "een vlot mondje" \\
\hline 112 & $\begin{array}{l}\text { "Na 'n heen en weer geka- } \\
\text { wel, klink dit selfs na onver- } \\
\text { valste Beiers" }\end{array}$ & $\begin{array}{l}\mathrm{Na} \text { 'n bietjie gesellige ge- } \\
\text { babbel word daar selfs ge- } \\
\text { praat in ... }\end{array}$ & $\begin{array}{l}\text { "Na enig gekeuvel heen en } \\
\text { weer klinkt er zelfs onver- } \\
\text { valst Bayerisch" }\end{array}$ \\
\hline 113 & "p & $p$ & "post ophalen" \\
\hline 114 & $\begin{array}{l}\text { "kaptein van die Suid- } \\
\text { Afrikaanse polisie" }\end{array}$ & 'oerder" & “'kapitein”" \\
\hline 114 & "uitsc & & “voor z’n rekening neemt” \\
\hline 114 & "b & $s p$ & "recherche \\
\hline 116 & $\begin{array}{l}\text { "Dwelms, prostitusie, sje- } \\
\text { biens: dis om 't ewe wat jy } \\
\text { jou by die mafia voorstel" }\end{array}$ & $\begin{array}{l}\text {... dit is net so erg as wat jy } \\
\text { by die mafia kan verwag }\end{array}$ & $\begin{array}{l}\text { "het doet niet onder voor } \\
\text { wat je je bij de mafia voor- } \\
\text { stelt" }\end{array}$ \\
\hline 119 & "nuutgebakte & dees & "die nieuwbakken ideeën” \\
\hline 120 & kkie druk" & & "als \\
\hline 120 & & & "voc \\
\hline 121 & $\begin{array}{l}\text { "aangevreet deur mot en } \\
\text { roes" }\end{array}$ & aangetas/beskadig & $\begin{array}{l}\text { "aangevreten door tijd en } \\
\text { mot" }\end{array}$ \\
\hline 122 & $\begin{array}{l}\text { "'n glimp van die parle- } \\
\text { mentsgebou" }\end{array}$ & 'n stukkie/'n blik op & $\begin{array}{l}\text { "en glimp". Ook in die } \mathrm{Ne} \text { - } \\
\text { derlands is dit waarskynlik } \\
\text { 'n anglisisme. }\end{array}$ \\
\hline 124 & "swa & s & "jasjes" \\
\hline 124 & "oog & L & "oog \\
\hline 124 & "dra so goed as niks;" & $\begin{array}{l}\text { dra (dikwels) byna geen } \\
\text { klere nie }\end{array}$ & "vaak zo goed als niks" \\
\hline 130 & $\begin{array}{l}\text { "afkeer in die Suid- } \\
\text { Afrikaanse regering" }\end{array}$ & afkeer van & "afkeer van" \\
\hline 131 & "immoraliteitswette" & 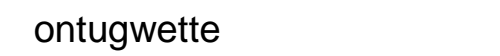 & "immoraliteitswetten" \\
\hline 132 & $\begin{array}{l}\text { "'n vreemde eend in die } \\
\text { trop" }\end{array}$ & $\begin{array}{l}\text { 'n vreemdeling in die ge- } \\
\text { selskap }\end{array}$ & $\begin{array}{l}\text { "een vreemde eend in de } \\
\text { bijt" }\end{array}$ \\
\hline 132 & "word hy ontslaan" & bedank hy & "neemt hij ontslag" \\
\hline 132 & "sosia & maatskaplike werkster & "sociaal werkster" \\
\hline 132 & "té beleef bedank" & $\begin{array}{l}\text { (op 'n keer) té beleef be- } \\
\text { dank }\end{array}$ & $\begin{array}{l}\text { "een keer al te beleefd be- } \\
\text { dankt" }\end{array}$ \\
\hline
\end{tabular}




\begin{tabular}{|c|c|c|c|}
\hline \multicolumn{4}{|c|}{ Taalfoute en registerprobleme (vervolg) } \\
\hline p. & Krog-vertaling & Korrekte vertaling & $\begin{array}{l}\text { Nederlands - } \\
\text { Van Woerden }\end{array}$ \\
\hline 132 & "Bantoestans" & Bantoetuislande & "Bantoestans" \\
\hline 132 & $\begin{array}{l}\text { "meedeel dat die Afrikaners } \\
\text { 'n agterlike volk is" }\end{array}$ & onomwonde sê dat ... & "onomwonden meedeelt" \\
\hline 133 & "grys klere" & 'n grys pak klere & "een grijs kostuum" \\
\hline 133 & "buig saam oor" & bekyk saam & "buigen zich" \\
\hline 134 & "sou wel beloof het" & belowe maar al te graag & "wil wel beloven" \\
\hline 134 & "by die tafel in te skuif" & mag saam eet & $\begin{array}{l}\text { "mag ... aan tafel aan- } \\
\text { schuiven" }\end{array}$ \\
\hline 135 & $\begin{array}{l}\text { "'n Ander bring van die } \\
\text { vrouens aan boord" }\end{array}$ & $\begin{array}{l}\text { En anders bring hulle die } \\
\text { vrouens aan boord }\end{array}$ & $\begin{array}{l}\text { "En anders brengen ze de } \\
\text { vrouwen aan boord" }\end{array}$ \\
\hline 136 & "grootkoppe" & leier & "kopstukken" \\
\hline 136 & "afkeer in" & van & "afkeer van” \\
\hline 136 & "klerk" & polisiebeampte & “agent” \\
\hline 137 & "hy haal ... verlede op" & $\begin{array}{l}\text { Hy onthou sy verlede pre- } \\
\text { sies }\end{array}$ & $\begin{array}{l}\text { "haalt met precisie zijn } \\
\text { verleden op" }\end{array}$ \\
\hline 137 & $\begin{array}{l}\text { "hy moet die gang op na } \\
\text { die toilet" }\end{array}$ & $\begin{array}{l}\text { hy moet in die gang na die } \\
\text { toilet toe gaan }\end{array}$ & $\begin{array}{l}\text { "hij moet op de gang naar } \\
\text { de wc" }\end{array}$ \\
\hline 137 & "opgelug" & verlig & "opgelucht" \\
\hline 137 & "hand op die blaas" & riende & "dikke maatjes" \\
\hline 138 & "Daardie Donderdag" & $\begin{array}{l}\text { Op Donderdag } 1 \text { Septem- } \\
\text { ber }\end{array}$ & $\begin{array}{l}\text { "Op donderdag de eerste } \\
\text { september ..." }\end{array}$ \\
\hline 138 & "aan boord" & na benede & "benedendeks" \\
\hline 138 & "diksak" & vets & "dikzak" \\
\hline 138 & "Hy klamp Demitrios vas" & $\begin{array}{l}\text { Hy dring hom aan Demitri- } \\
\text { os op }\end{array}$ & "Hy klampt hem aan" \\
\hline 139 & "Bantoestans" & Bantoetuislande & "Banttoestans" \\
\hline 140 & $\begin{array}{l}\text { "... by hom verbyloop. Buy- } \\
\text { tendag verdwyn ..." }\end{array}$ & $\begin{array}{l}\text {... by hom verbyloop. Hy } \\
\text { loop die vergadersaal binne } \\
\text { agter die geselskap aan }\end{array}$ & $\begin{array}{l}\text { "... voorbijloopt. Achter het } \\
\text { geselschap aan loopt hij de } \\
\text { vergaderzaal binnen. Buy- } \\
\text { tendach..." }\end{array}$ \\
\hline 141 & "ontsielde liggaam" & lewelose liggaam & "ontsielde" \\
\hline 142 & $\begin{array}{l}\text { "... vir ons Afrikane nie. Hy } \\
\text { het heeltemal ..." }\end{array}$ & Hulle het heeltemal & "Ze zijn echt te ver gegaan" \\
\hline 142 & "het u gelyk" & is & "heeft u gelijk" \\
\hline 142 & "Minister-President" & Eerste Minister & "de minister-president" \\
\hline 144 & $\begin{array}{l}\text { "... uit lyfeienes (ja, daar is } \\
\text { so 'n woord)" }\end{array}$ & lyfeienes, slawe ...” & $\begin{array}{l}\text { "lijfeigenen, slaven die..." } \\
\text { Hierdie aantekening van } \\
\text { Krog op die manuskrip het } \\
\text { sy plek na die teks gevind. }\end{array}$ \\
\hline 144 & "present" & geskenk & "cadeau deed" \\
\hline 144 & "op die suidelike halfrond" & in die suidelike halfrond & "op het zuidelijk halfrond" \\
\hline 145 & $\begin{array}{l}\text { "... in die herinnering be- } \\
\text { waar en per oproep beskik- } \\
\text { baar" }\end{array}$ & $\begin{array}{l}\text { in die geheue vasgelê en } \\
\text { dadelik oproepbaar }\end{array}$ & "en op afroep beschikbaar" \\
\hline $\begin{array}{l}145 \\
117\end{array}$ & "sit hom af" & skrik hom af & "schrikt hem af" \\
\hline 147 & "spoegsat" & boos/dik die donder in & "spuugzat" \\
\hline 148 & $\begin{array}{l}\text { "... ook om kompeterende } \\
\text { guerillabendes wat teen } \\
\text { mekaar veg sedert die jare } \\
\text { dertig" }\end{array}$ & $\begin{array}{l}\text { om 'n guerillaoorlog tussen } \\
\text { vyandige bendes wat al } \\
\text { sedert die dertigerjare } \\
\text { voortsleep }\end{array}$ & $\begin{array}{l}\text { "om een guerilla tussen } \\
\text { rivaliserende bendes die } \\
\text { zich al sinds de jaren dertig } \\
\text { voortsleept" }\end{array}$ \\
\hline
\end{tabular}




\begin{tabular}{|c|c|c|c|}
\hline \multicolumn{4}{|c|}{ Taalfoute en registerprobleme (vervolg) } \\
\hline p. & Krog-vertaling & Korrekte vertaling & $\begin{array}{l}\text { Nederlands - } \\
\text { Van Woerden }\end{array}$ \\
\hline 148 & $\begin{array}{l}\text { "... beeld ... en sy wraak- } \\
\text { sua bly hana" }\end{array}$ & $\begin{array}{l}\text { die beeld bly voortduur/ } \\
\text { bestaan }\end{array}$ & "blijft hangen" \\
\hline 149 & $\begin{array}{l}\text { "Die 'ulama' ... } \\
\text { skoorvoetend toegegee" }\end{array}$ & $\begin{array}{l}\text { Verskeie gedeeltes word } \\
\text { hier weggelaat in die Afri- } \\
\text { kaanse vertaling: "Die } \\
\text { 'ulama' [die Islamitiese } \\
\text { geestelikheid] ... ten gunste } \\
\text { van die regime uitgespreek } \\
\text { nie [iets waarop die Chris- } \\
\text { telike kerke hul nie op kan } \\
\text { beroep nie] maar die soli- } \\
\text { dariteit ... word [in eie } \\
\text { kring] skoorvoetend toege- } \\
\text { gee. Vgl. Een mond vol } \\
\text { glas, p. } 177 \text {. }\end{array}$ & \\
\hline 149 & $\begin{array}{l}\text { "Die beweging opereer in } \\
\text { ieder geval op 'n sterk af- } \\
\text { keer in die ANC" }\end{array}$ & $\begin{array}{l}\text { Die beweging word in ieder } \\
\text { geval gedryf deur 'n felle af- } \\
\text { keer van die ANC }\end{array}$ & $\begin{array}{l}\text { “... drijft in ieder geval op } \\
\text { een rabiate afkeer van de } \\
\text { ANC" }\end{array}$ \\
\hline 150 & $\begin{array}{l}\text { "dié keer in 'n Moslemgroen } \\
\text { jassie geklee?" }\end{array}$ & $\begin{array}{l}\text { wat dié keer 'n Moslem- } \\
\text { groen baadjie aantrek? }\end{array}$ & $\begin{array}{l}\text { "in een moslimgroen jasje } \\
\text { gestoken?" }\end{array}$ \\
\hline 150 & "boewe" & skorriemorries & "schorem" \\
\hline 150 & $\begin{array}{l}\text { "wel bereid om sy pistool } \\
\text { aan die wilgerbome te } \\
\text { hang" }\end{array}$ & geweld af te sweer & $\begin{array}{l}\text { "zijn pistool wel aan de } \\
\text { wilgers hangen" }\end{array}$ \\
\hline 151 & $\begin{array}{l}\text { "Aan die Kaap word dring- } \\
\text { end geluid gemaak" }\end{array}$ & $\begin{array}{l}\text { In die Kaap het dinge tot } \\
\text { uitbarsting gekom }\end{array}$ & "is het dringen geblazen" \\
\hline 151 & "Die stasie gee hoog op ..." & hemel nogal ... op & "hoogt opgeeft over" \\
\hline 151 & "die verkeer gorrel" & spoel & "gorgelt" \\
\hline 152 & $\begin{array}{l}\text { "Ons ry strak in die spore } \\
\text { van ..." }\end{array}$ & vas & "strak" \\
\hline $\begin{array}{l}52 / \\
53\end{array}$ & $\begin{array}{l}\text { "Soos altyd skeer die } \\
\text { meeue oor die hawekafee. } \\
\text { Pagad? Community Out- } \\
\text { reach Forum ...", ens. }\end{array}$ & $\begin{array}{l}\text { Die ingrypende verande- } \\
\text { rings hier word onder die } \\
\text { afdeling "Ideologiese ver- } \\
\text { anderings" behandel. }\end{array}$ & \\
\hline 153 & $\begin{array}{l}\text { "wat ek in Krugersdorp ont- } \\
\text { moet, 'n uur se ry van } \\
\text { Johannesburg, dra ..." }\end{array}$ & $\begin{array}{l}\text { Krugersdorp, 'n uur se ry } \\
\text { van Johannesburg af, ont- } \\
\text { moet }\end{array}$ & $\begin{array}{l}\text { "in Krugersdorp ontmoet, } \\
\text { een uur rijden van Johan- } \\
\text { nesburg" }\end{array}$ \\
\hline 153 & "akrielhempies" & sintetiese hempies & "acrylhemdjes" \\
\hline 153 & $\begin{array}{l}\text { "Is die gebrek aan versie- } \\
\text { ring ...?" }\end{array}$ & $\begin{array}{l}\text { Is die gebrek aan goeie } \\
\text { smaak ...? }\end{array}$ & "decorum" \\
\hline 153 & $\begin{array}{l}\text { "Die veel armer swart } \\
\text { mense lyk weer asof hul } \\
\text { daartéén aantrek" }\end{array}$ & $\begin{array}{l}\text { dit lyk asof die arm swart } \\
\text { mense daarteenoor hul juis } \\
\text { anders aantrek }\end{array}$ & $\begin{array}{l}\text { "De nóg armer zwarten } \\
\text { lijken zich daarentegen te } \\
\text { verkleden. Ze kleden zich } \\
\text { áán, niet uit" }\end{array}$ \\
\hline 154 & $\begin{array}{l}\text { "voorregte van Apartheid as } \\
\text { oplossing bedoel was" }\end{array}$ & $\begin{array}{l}\text { van Apartheid [vroeër] as } \\
\text { oplossing bedoel was }\end{array}$ & "ooit een oplossing" \\
\hline 155 & "klankboks" & luidspreker & "geluidsboxen" \\
\hline 155 & "biertap" & kroegtoonbank & "de tap" \\
\hline 156 & $\begin{array}{l}\text { "Is die juiste paaie wel be- } \\
\text { wandelbaar? }\end{array}$ & $\begin{array}{l}\text { Is die regte weë wel ge- } \\
\text { volg? }\end{array}$ & $\begin{array}{l}\text { "Zijn de juiste paden wel } \\
\text { bewandeld?" }\end{array}$ \\
\hline
\end{tabular}




\begin{tabular}{|c|c|c|c|}
\hline \multicolumn{4}{|c|}{ Taalfoute en registerprobleme (vervolg) } \\
\hline p. & Krog-vertaling & Korrekte vertaling & $\begin{array}{l}\text { Nederlands - } \\
\text { Van Woerden }\end{array}$ \\
\hline 157 & $\begin{array}{l}\text { "Alleen adjunkpresident } \\
\text { Mbeki ..." }\end{array}$ & Slegs & "Alleen" \\
\hline 158 & "'n Mond vol glas" & Die ruimte/do & "Het domein van glas" \\
\hline 158 & $\begin{array}{l}\text { "reik matrone Geyser 'n } \\
\text { eienaardige hand ..." }\end{array}$ & $\begin{array}{l}\text { reik matrone Geyser 'n } \\
\text { vriendelike hand }\end{array}$ & "een \\
\hline 159 & $\begin{array}{l}\text { "asof hy vandag van voor af } \\
\text { verbyster is" }\end{array}$ & $\begin{array}{l}\text { asof in sy verbystering hy } \\
\text { vandag daarvoor te moeg } \\
\text { is }\end{array}$ & $\begin{array}{l}\text { "alsof het hem vandaag } \\
\text { weer verbijsterd te moede } \\
\text { is" }\end{array}$ \\
\hline 160 & "felgroen" & helder groen & "felgroene" \\
\hline 160 & $\begin{array}{l}\text { "Sy voete is in ... pantoffels } \\
\text { versteek" }\end{array}$ & ge & "gestoken" \\
\hline 160 & $\begin{array}{l}\text { "'Ek het alles gedra na my } \\
\text { vermoë" }\end{array}$ & verduur & "gedragen" \\
\hline 162 & $\begin{array}{l}\text { "(Maar die) vergelyking wil } \\
\text { nie uitwerk nie" }\end{array}$ & $\begin{array}{l}\text { Maar die vergelyking is } \\
\text { swak }\end{array}$ & "gaat mank" \\
\hline 162 & "riksjajongetjies" & riksjaseuntjies & "riksja-jongens" \\
\hline 164 & $\begin{array}{l}\text { "Sy kindertyd ... word op- } \\
\text { gevoer" }\end{array}$ & "kom ter sprake & "passeert de revue" \\
\hline 164 & "'n dobbelsteentjie opgooi" & 'n klein spoelklippie opvis & $\begin{array}{l}\text { "een kiezelsteentje op- } \\
\text { werpt" }\end{array}$ \\
\hline 164 & $\begin{array}{l}\text { "om te improviseer uit sy } \\
\text { verlede ...om ander koerse } \\
\text { met sy geskiedenis te loop" }\end{array}$ & $\begin{array}{l}\text { maak die indruk van ie- } \\
\text { mand wat daaraan ge- } \\
\text { woond is om te improviseer } \\
\text { met sy geskiedenis ... ge- } \\
\text { dwing word om aan die } \\
\text { loop te gaan met sy eie ge- } \\
\text { skiedenis }\end{array}$ & $\begin{array}{l}\text { "te improviseren met zijn } \\
\text { verleden ... Alsof hij tel- } \\
\text { kens gedwongen wordt om } \\
\text { met zijn geschiedenis aan } \\
\text { de haal te gaan" }\end{array}$ \\
\hline 165 & "totdat dit 'n eie aard kry" & le & "het een aard heeft" \\
\hline 165 & $\begin{array}{l}\text { ng hale ... uit volle } \\
\text { oes sing" }\end{array}$ & uit volle bors ... geesdriftig & $\begin{array}{l}\text { "lange halen losgebarsen } \\
\text {... ten besten" }\end{array}$ \\
\hline 165 & "pc & & "plusfours" \\
\hline 165 & "prik & stukkie & $\begin{array}{l}\text { "waar hier en daar stemmig } \\
\text { rood is afgezet" }\end{array}$ \\
\hline 166 & $\begin{array}{l}\text { "Boonop het hy na sy 'vry- } \\
\text { lating' kinds geword met } \\
\text { doof en mal op die koop } \\
\text { toe" }\end{array}$ & $\begin{array}{l}\text { en na sy 'vrylating' is be- } \\
\text { weer dat hy kinds is en } \\
\text { doof en op die koop toe ook } \\
\text { nog (voortdurend) sanik }\end{array}$ & $\begin{array}{l}\text { "zou hij kinds zijn gewor- } \\
\text { den en doof en malende op } \\
\text { de koop toe" }\end{array}$ \\
\hline 166 & $\begin{array}{l}\text { "Kortom: ons het alles } \\
\text { netjies in 'n ry" }\end{array}$ & ons het alles georden & $\begin{array}{l}\text { "op een rytje, zoals dat } \\
\text { heet" }\end{array}$ \\
\hline 166 & $\begin{array}{l}\text { "Demitrios daarenteen, het } \\
\text { die elemente van sy lewe } \\
\text { nie in 'n ry nie" }\end{array}$ & nie georden nie & "heeft ze niet op een rijtje" \\
\hline 167 & "verborge" & & "verbogen" \\
\hline 170 & $\begin{array}{l}\text { "Hy het sy hand oor my } \\
\text { gehou" }\end{array}$ & my beskerm & $\begin{array}{l}\text { "Hij hield me de hand bo- } \\
\text { ven het hoofd" }\end{array}$ \\
\hline 170 & $\begin{array}{l}\text { "Daarom behandel sy hom } \\
\text { so" }\end{array}$ & Daarom het sy so opgetree & "Daarom handelt ze zo" \\
\hline
\end{tabular}




\begin{tabular}{|c|c|c|c|}
\hline \multicolumn{4}{|c|}{ Taalfoute en registerprobleme (vervolg) } \\
\hline p. & Krog-vertaling & Korrekte verta & $\begin{array}{l}\text { Nederlands - } \\
\text { Van Woerden }\end{array}$ \\
\hline 171 & $\begin{array}{l}\text { "Hy ly nog steeds onder die } \\
\text { stigma van sy reputasie en } \\
\text { die politieke implikasies } \\
\text { daarvan" }\end{array}$ & $\begin{array}{l}\text { reputasie [en hulle is dood- } \\
\text { bang vir] die politieke } \\
\text { implikasies }[\ldots]\end{array}$ & $\begin{array}{l}\text { "het stigma van zijn repu- } \\
\text { tatie en ze zijn als de dood } \\
\text { voor de politieke implica- } \\
\text { ties" }\end{array}$ \\
\hline 172 & "weining" & & "weinig" \\
\hline 172 & "sosiale werkster" & $\begin{array}{l}\text { maatskaplike werkster of } \\
\text { eerder welsynsbeampte }\end{array}$ & "welzijnswerkster" \\
\hline 172 & "bruin mense" & & $\begin{array}{l}\text { "de kleurling". Hier gaan dit } \\
\text { om mense van kleur. }\end{array}$ \\
\hline 172 & "afkeer ... aan" & at & "afkeer ... van" \\
\hline & "bruin & & "kleurling" \\
\hline 173 & $\begin{array}{l}\text { "Van 'n mengelmoes-same- } \\
\text { lewing - soos dit geslagte } \\
\text { lank deur wit Suid-Afrika- } \\
\text { ners beskryf is, in afsku vir } \\
\text {..." }\end{array}$ & $\begin{array}{l}\text { 'n "mengelmoes-same- } \\
\text { lewing" ... vol afsku }\end{array}$ & $\begin{array}{l}\text { "van een mengelmoes- } \\
\text { samelewing vol afschuw ... } \\
\text { vol afschuw ... voor ..." }\end{array}$ \\
\hline 174 & "Op dié Vrydag ..." & & "Op vrijdag is er ..." \\
\hline & $\begin{array}{l}\text { "wat nou en dan losbars. } \\
\text { Die stank ..." }\end{array}$ & $\begin{array}{l}\text { losbars. [Die lawaai is oor- } \\
\text { verdowend.] Die stank ... }\end{array}$ & $\begin{array}{l}\text { "overstemt. Het lawaai is } \\
\text { oorverdovend. De stank..." }\end{array}$ \\
\hline 174 & $\begin{array}{l}\text { "Ek skuif ... 'n stoel langs } \\
\text { hom in" }\end{array}$ & Ek gaan sit langs hom & $\begin{array}{l}\text { "Ik schuif ... een stoel bij } \\
\text { hem aan" }\end{array}$ \\
\hline 174 & "nie pap kan sê nie" & nie meer kan praat nie & $\begin{array}{l}\text { "die geen pap meer kan } \\
\text { zeggen" }\end{array}$ \\
\hline 176 & $\begin{array}{l}\text { "Dit is iets wat hom voorge- } \\
\text { doen het" }\end{array}$ & wat gebeur/plaasgevind het & "dat zich voordeet" \\
\hline 179 & "sosiale werker" & maatskaplike werker & $\begin{array}{l}\text { [ontbreek in oorspronklike } \\
\text { teks] }\end{array}$ \\
\hline 181 & $\begin{array}{l}\text { "Dit gaan dus veral daaroor } \\
\text { om die mate van skyn te } \\
\text { verantwoord" }\end{array}$ & $\begin{array}{l}\text { verantwoor- } \\
\text { yn }\end{array}$ & $\begin{array}{l}\text { "Het gaat om een te verant- } \\
\text { woorden mate van schijn" }\end{array}$ \\
\hline $\begin{array}{l}182 \\
183\end{array}$ & \multicolumn{3}{|c|}{$\begin{array}{l}\text { "'(w)ie agter die skerm die toutjies trek, weet niemand'”. Dié aanhaling kom uit die teks } \\
\text { self en word op p. } 90 \text { deur Krog anders vertaal: "Wie agter die skerm die toutjies trek, is } \\
\text { moeilik om te sê." Dit is 'n voorbeeld van die slordigheid van dié vertaling. } \\
\text { "'Na afloop van die doop word daar vrolik gelag en in die sand gestoei'”. Op p. } 83 \text { van } \\
\text { die teks vertaal Krog dié sinsnede as "Na afloop van die seremonie word daar vrolik } \\
\text { gelag en in die sand gestoei." }\end{array}$} \\
\hline 182 & $\begin{array}{l}\text { "vleeslike muse" } \\
\text { "'n gewetenlose bedienaar } \\
\text { van die apartheidsregime" }\end{array}$ & tente & $\begin{array}{l}\text { "stoffelijke muze" } \\
\text { "een uitzonderlijke } \\
\text { schurk" }\end{array}$ \\
\hline 83 & \multicolumn{3}{|c|}{$\begin{array}{l}\text { 'n Vreemde apologie (wat ook in die oorspronklike teks verskyn, is Van Woerden se apo- } \\
\text { logie vir sy oppervlakkige behandeling van die Verwoerd-figuur (sien ook Van Coller, } \\
2001: 151 \text { e.v.). Dit was nie sy "voorneme om die lewe van Verwoerd te behandel nie, maar } \\
\text { te wys op feite wat relevant is vir die Nederlandse verband." In die oorspronklike staan: "ik } \\
\text { vermeld slechts de voor de Nederlandse lezer relevante feiten" wat darem sin maak. } \\
\text { Enkele verwysings in die oorspronklike teks word weggelaat, o.a. die opmerking dat die } \\
\text { Hollandse gebruik om fiets te ry gou deur immigrante afgeleer is: "een tweewieler was } \\
\text { immers bij uitstek het voertuig van 'kaffers en bedienden'” (p. 215: Een mond vol glas). 'n } \\
\text { Lang verwysing na die Griekse heldegedig word ook weggelaat (p. 184). }\end{array}$} \\
\hline
\end{tabular}




\begin{tabular}{|l|l|l|l|}
\hline \multicolumn{1}{|l|}{ Taalfoute en registerprobleme (vervolg) } \\
p. & Krog-vertaling & Korrekte vertaling & $\begin{array}{l}\text { Nederlands - } \\
\text { Van Woerden }\end{array}$ \\
\hline 184 & $\begin{array}{l}\text { "twee formidabel-gespierde } \\
\text { klerekaste" (sic!) } \\
\text { "Pratt pleeg selfmoord [on- } \\
\text { der verdagte omstandighe- } \\
\text { de] in 'n ..." }\end{array}$ & twee gespierde vleispaleise & $\begin{array}{l}\text { "klerenkasten" } \\
\text { "Pratt pleegt zelfmoord in } \\
\text { een psychiatrische inrich- } \\
\text { ting ...". Wie sou verant- } \\
\text { woordelik wees vir die toe- } \\
\text { voeging en waarom? } \\
\text { "naar verluidt". 'n Wegla- } \\
\text { ting is dat Van den Berg } \\
\text { gemartel ("afgetuig") is. }\end{array}$ \\
\hline 186 & $\begin{array}{l}\text { "J. Van den Berg, dié ver- } \\
\text { antwoordelike ..." }\end{array}$ & $\begin{array}{l}\text { soos beweer } \\
188\end{array}$ & $\begin{array}{l}\text { Woerden se boek (twee jaar eerder) heet dit presies dieselfde. } \\
\text { Vernon February se boek se verskyningsdatum word aangegee as 1918; in die oor- } \\
\text { spronklike teks is die datum "1981". } \\
\text { 'n Nuwe invoeging is Van Woerden se dankbetuiging aan sy uitgewer en vertaler wat } \\
\text { verdien om "toegegooi te word onder pluime en eikeblaarloof." Ten slotte ontbreek die } \\
\text { woordverklarings wat aan die oorspronklike teks toegevoeg is. }\end{array}$ \\
\hline
\end{tabular}

Van die grootste probleme by vertaling is interpretasieprobleme (ten opsigte van die tekstuele en kontekstuele aspekte van die bronteks) en appropriasieprobleme (aanpassing van aspekte van die brontaalkultuur in die doeltaalkultuur). Eersgenoemde aspek het onder andere te make met die sogenaamde betekenis van die teks, maar ook met die intertekstuele verbande. Hoewel party vertalers die mening toegedaan is dat hulle slegs die teks vertaal, sou dit onverantwoordelik wees om standaardinterpretasies - en implikasies daarvan - te negeer. Die tweede aspek vereis 'n deeglike kennis van én die bron- én die doelkultuur ten einde ' $n$ mate van simmetrie in die vertaling te bereik. Sodanige kennis kan bykans beskryf word as kulturele semiotiek omdat die vertaler andersins bepaalde tekens, waaronder referensiële aspekte, gewoon mislees. In hul voorlesing tydens die Nederlandse Taalunie-Vertalerswerkswinkel, gee Marie-Thérese Claes en Marinel Gerritsen, verskeie voorbeelde wat hieronder sou kon tuishoort.

Antjie Krog is eintlik gelukkig omdat sy albei problematiese aspekte gespaar gebly het in haar vertaling. Van Woerden se teks speel in SuidAfrika af en handel oor Suid-Afrikaners; 'n feit wat kulturele probleme goedskiks uitskakel. Wat interpretasieprobleme betref, kon sy haar verlaat op die skrywer wat ten spyte van die gevare verbonde hieraan (dink maar aan the intentional fallacy), haar tydens hul samewerking (onder meer ' $n$ intensiewe maandlange sessie in Amsterdam) deeglik kon inlig oor sy teks. 
In die voorafgaande gedeelte van die artikel is 'n redelik volledige oorsig gegee van vertaalprobleme. Uiteraard veronderstel vertaling voortdurend keuses. Hoewel ek by tye skerp van Krog se keuses verskil (van die leksikale vlak, tot by die sintaktiese, semantiese en daarom ook pragmatiese vlak), word nie elke enkele geval in die oorsig opgeneem nie dit sou neerkom op 'n alternatiewe vertaling. Krog se vertaling vertoon myns insiens mankamente wat betref tekstuele interpretasie (soos ten opsigte van die titel), begrip van Nederlandse idiome en benamings, Nederlandse woordbetekenis en register en vreemd genoeg vir 'n digter, 'n onvermoë om te vertaal in korrekte en soepel Afrikaans. Voorts is daar talle wysigings van ideologiese aard wat neerkom op verwerking en nie vertaling nie.

\section{Gevolgtrekking}

Om op te som. Krog se titelkeuse werk verengend omdat dit die klem te veel plaas op die teoretiese aspekte van herskepping van die verlede en die bykans aktiewe (en selfs traumatiese) deelname van skrywer en leser by die herskepping van die verlede - geïmpliseer in Van Woerden se oorspronklike titel - negeer. Terugblikke word nie altyd suksevol gesinjaleer nie en die sporadiese gebruik van die Perfektum sou in hierdie opsig dalk 'n oplossing kon bied. Die grootste gebreke lê egter op die vlak van woord- en sinsbetekenisse. Op grond van die feit dat Krog nie die betekenis van Nederlandse woorde soos "agent", "jasje", "volk", "Minister-president", ensovoorts, en idiomatiese uitdrukkings soos "grasduint", "een vlot mondje", "aan de wilgers hangen", ensovoorts ken nie, blyk reeds dat sy nie oor die nodige kennis beskik om so 'n vertaling suksesvol uit te voer nie.

\section{Bibliografie}

Anon. 2000a. Boek oor Tsafendas gaan opslae maak. Die Volksblad, Feb. 21.

Anon. 2000b. En so voel Antjie Krog oor háár vertaling. Insig Boekeseksie: 44, Maart. Anon. 2000c. 'n Wéreld van glas. Boekewêreld: 7, Maart 20.

Anon. 2000d. Sterboek. Uitsoek leesstof. Huisgenoot: 127, April 13.

Anon. 2000e. Kortjes. Zuid-Afrika, 77(4):40, April.

Benson, Larry D. 1987. The Riverside Chaucer. Oxford : Oxford University Press.

Biberauer, Theresa. 2000. In Search of the Real Tsafendas. The Sunday Independent:13, June 18.

Booyens, Hannelie \& Nieuwoudt, Stephanie. 2000. Antwoorde op absoluut bleddie niks (onderhoud met Antjie Krog per E-pos deur Hannelie Booyens en Stephanie Nieuwoudt). Beeld: 4, Maart 21.

Brink, André P. 2000. Sad life and times of Tsafendas. Sunday Times: May 7.

Britz, Etienne. 1998. Nederlandse en Vlaamse receptie van vertaalde Afrikaanstalige literatuur: voorlopige notities. Filter. Tijdschrift voor Vertalen \& Vertaalwetenschap, 5(3):14-30. 
De Jong-Goossens, Riet. 1998. Vertalen in het praktijk. Filter. Tijdschrift voor Vertalen \& Vertaalwetenschap, 5(3):83-90.

De Lange, Barbara. 1998. Filter. Tijdschrift voor Vertalen \& Vertaalwetenschap, $5(3): 48-55$.

De Stadler, Leon. 1998. Filter. Tijdschrift voor Vertalen \& Vertaalwetenschap, 5(3):281.

Denissen, Frans. 2000. Staat er wat er staat? Nieuw Wereldtydschrift, 10:69-77, December.

Dorleijn, Gillis. 1996. "Daarginds kent men u door Coster!" Paul van Ostayen in het Nederlandse literaire veld. In: Peeters, Patrick \& Spinoy, Erik. (reds.) Het vouwbeen van de lezer. Over literatuuropvattingen. Leuven : Peeters. Paul van Ostaijen Instituut. p. 51-70.

Dorsman, Robert. 1998. Als een (lach)spiegel in raadselen. Vertalen uit het Afrikaans. Filter. Tijdschrift voor Vertalen \& Vertaalwetenschap, 5(3):3-13.

Hermans, Theo. 2000. Vertaling en vertaler: over receptie en 'zichtbaarheid'. Openbare voorlesing. Zomercursus literair vertaling, Utrecht en Antwerpen, 30 Augustus.

Hofstede, Geert.1991. Allemaal andersdenkenden. Omgaan met cultuurverschillen. Amsterdam : Contact.

Holmes, J.S. 1988 [1972]. The name and nature of translational studies. In: Holmes, J.S. Translated! Papers on Literary Translation and Translational Studies. Amsterdam : Rodopi. p. 67-80.

Hough, Barry. 2000. Roman wysig beeld van Tsafendas. Rapport: 2, April 9.

Hugo, Daniel 1998. Nederlandse literatuur in Afrikaanse vertaling. Filter. Tijdschrift voor Vertalen \& Vertaalwetenschap, 5(3):39-45.

Krog, Antjie. 2000. "Nota van die vertaler". In: Domein van glas. [Vertaling van Henk van Woerden se roman Een mond vol glas.]. Kaapstad: Quellerie. p. 190.

Lambert, J. \& Van Gorp, H. 1985. On Describing Translations. In: Hermans, T. The Manipulation of Literature. Studies in Literary Translation. London : Croom Helm. p. 42-53.

Lefevere, André \& Vanderauwera, R. (reds.) 1979. Vertaalwetenschap. Literatuur, wetenschap, vertaling en vertalen. Leuven : Acco.

Legouis, E. \& Cazamian, L.F. 1967 [1926]. A History of English Literature. London \& Toronto : Dent.

Marais, Jaap. 1992. Die era van Verwoerd. Pretoria : Aktuele Publikasies.

Marais, Jaap. 2000a. Linkse Afrikaner en Afrikaanse vertaalster wil Verwoerd die misdadiger en Tsafendas die slagoffer maak. Deel I, Die Afrikaner: 7, Mei 5-11.

Marais, Jaap. 2000b. Linkse Afrikaner en Afrikaanse vertaalster wil Verwoerd die misdadiger en Tsafendas die slagoffer maak. Deel II, Die Afrikaner: 7, Mei 1218.

Naaijkens, Ton. 2000. Vertaalkritiek. Voorlesing. Zomercursus Literair Vertalen, Utrecht en Antwerpen, 24-31 Augustus.

Naudé, J.A. 2001. Vertaalkunde vandag: 'n Oorsig. Bygewerkte kopie van 'n lesing gelewer by die "Workshop Literaire Vertaling" van die Nederlandse Taalunie by die U.V., 29-31 Maart 2000. Tydskrif vir Geesteswetenskappe, 14(3):177-194, Sept.

Nord, Christina. 1991. Text Analysis in Translator: Theory, Methodology and Didactic application of a model for translation oriented text analysis. Amsterdam : Rodopi.

Picard, Jan H. 1988. Vertalers en vertalings. Pretoria : Serva-uitgewers.

Postel, Gitte. 1999. Een achtergelaten toekomst. Vrij Nederland, Jan. 16. 
Pretorius, S.J. 1972. Die stryd tussen hemel en hel. 'n Poging tot die verklaring van Vondel se Christelike epos, "Johannes de Boetgezant". Pretoria : Universiteit van Suid-Afrika.

Roodt, Dan. 2000. Van Woerden, Verwoerd en Tsafendas. Ons Erfdeel, 43(2):273275.

Schiferli, Victor. 2001. Portret van een vertaler: Gregor Seferens. Niewsbrief Letteren. 9(3): 2-3,Winter.

Snell-Hornby, Mary. 1995 [1988]. Translation Studies. An Integrated Approach. Revised Edition. Amsterdam/Philadelphia : Benjamins.

Snyman, W. 2000. Resensie: Een mond vol glas. Cape Times: March, 24.

Toury, Gideon. 1979. Literatuur in vertaling - Systeem en norm: voor een doelgerichte aanpak van de literaire vertaling. In: Lefevere, André \& Vanderauwera, R. (reds.) 1979. Vertaalwetenschap. Literatuur, wetenschap, vertaling en vertalen. Leuven : Acco. p. 32-52.

Van Coller, H.P. 2000. Lewe van Tsafendas knap beskryf. Volksblad: 8, Maart 27.

Van Coller, H.P. 2001. Proewe van 'n rekonstruksie: Een mond vol glas deur Henk van Woerden. Literator, 22(1):137-154, April.

Van den Bergh, Erik. 2001. Blik van buiten: Zuid-Afrikaanse literatuur in Nederland. Stilet, 12(2):63-76, September.

Van den Ouden, Barbara. 2000. Beleid voor de promotie van Nederlandstalige literatuur. Zomercursus Literair Vertalen, Utrecht en Antwerpen, 29 Augustus.

Van der Elst. J. e.a. 1988. Momente uit die Nederlandse letterkunde. Pretoria \& Kaapstad : Academica.

Van Gorp, Hendrik. 1979. Vertaling en evolutie van een literair genre: de Europese picareske roman in de zeventiende en de achttiende eeuw. In: Lefevere, André \& Vanderauwera, R. (reds.) Vertaalwetenschap. Literatuur, wetenschap, vertaling en vertalen. Leuven : Acco. p. 86-97.

Van Gorp, Hendrik, Delabastita, Dirk, Ghesquiere, Rita. 1998. Lexicon van literaire termen. Groningen : Nijhoff.

Venter, Christél. 2002. 'n Sisteem-teoretiese perspektief op die vertaling van SuidAfrikaanse literatuur in Nederlands. Bloemfontein : Universiteit van die Vrystaat. Ongepubliseerde proefskrif.

Venter, L.S. 2000. Die halfgebakte Hollander en die halwe Griek. Tsafendas-storie nou roman. Beeld: 15, Mei 29.

Vogelaar, J.F. 1998. Resensie van Een mond vol glas. Verwysings ontbreek op fotokopie.

Wasserman, Herman. 2000. Boeiende verhaal uit doofpot gelig. Die Burger: 15, April 19.

Wasserman, Herman. 2000. Onderhoud met Henk van Woerden. Die Burger, Maart 25.

Yahalom, Shelly. 1979. Het gedrag van een literair polyssysteem in een crisissituatie: intersystemische contacten en soorten vertalingen. In: Lefevere, André \& Vanderauwera, R. (reds.) Vertaalwetenschap. Literatuur, wetenschap, vertaling en vertalen. Leuven : Acco. p. 64-85.

\section{Kernbegrippe:}

literêre vertaling

Van Woerden, $\mathrm{H}$.: Een mond vol glas

vertaalprobleme

vertaalteorie 


\section{Key concepts:}

literary translation

theory of translation

translation problems

Van Woerden, H.: Een mond vol glas 
